\title{
空間的な摇れやすさ分布特性を考慮した 工学的基盤面の加速度応答スペクトルの推定
}

\author{
新垣芳一1）、栗田哲史 ${ }^{2 ）}$ 、安中正 ${ }^{3)}$ 、森欣樹4) \\ 1) 正会員 東電設計株式会社、修士（工学） \\ e-mail :shingaki@tepsco.co.jp \\ 2) 正会員 東電設計株式会社、博士（工学） \\ e-mail : kurita@tepsco.co.jp \\ 3) 正会員 東電設計株式会社、理修 \\ e-mail :annaka@tepsco.co.jp \\ 4) 東京電力株式会社 \\ e-mail: mori.yoshiki@tepco.co.jp
}

\begin{abstract}
要 約
富士山南東部地域を対象に地震観測記録を利用寸ることで、工学的基盤面における摇れや すさのゾーニングを検討した。摇れやすさの指標には、選定した地震観測記録から算定し た解放工学的基盤波の加速度応答スペクトルを既存の推定式で除した比（応答スペクトル 比）を用いた。摇れやすさを空間的に分析し、地震観測点ごとの平均応答スペクトル比の 形状や地理的・地形的条件と地質を考慮することにより検討した結果、富士山南東部地域 を 5 つのグループに分類した。ゾーニング結果を基に、各グループについて摇れや寸さの 特性を反映した地点補正倍率を作成した。摇れや寸さ分布特性はこの地点補正倍率により 考慮することができ、これを既存の推定式に乗じる方法を、広域を対象とした工学的基盤 面の加速度応答スペクトルの推定方法として提案する。
\end{abstract}

キーワード： 空間的摇れやすさ、ゾーニング、加速度応答スペクトル、地形、地質

\section{1. はじめに}

設計用の入力地震動を推定する方法の 1 つとして、距離減衰式による経験的手法がある。距離減衰式 は必要なパラメータを設定すれば、想定地震に対する対象サイトの PGA や PGV 等の最大值、または応 答スペクトルを簡便に推定することができ、現在に至るまで数多くの式が提案されている。距離減衰式 は地震の規模を示すマグニチュード、震源からの距離、震源断層の深さの 3 つの諸元を基本としている が、距離減衰式によってはより複雑なパラメータを必要とする。設計用の入力地震動は距離減衰式によ る応答スペクトルで推定することが多いが、使用する距離减衰式によって推定結果は異なる。これは距 離減衰式の回帰分析を実施するにあたり、複数の地震観測点で収集された複数の地震観測記録を反映さ せ、回帰時には平均值が用いられるが、距離減衰式によって反映しているサイトや記録が違うことが原 因の 1 つとして挙げられる。また、工学的基盤面の地震動特性は一様ではなく地点ごとに異なっている ため、距離減衰式の回帰時には地点補正の項が考慮されている。回帰分析に使用されたサイトについて はその地点補正の項を考慮することで精度の高い推定が可能となるが、それ以外のサイトでは適応する 
ことはできない。距離減衰式によっては、深層地盤の特性を取り込んだものもあり、例えば、NGA プロ ジェクトでは Abrahamson and Silva ${ }^{12)}$ や Campbell and Bozorgnia ${ }^{34)}$ 、Chiou and Youngs ${ }^{5 /}$ にるる距離減衰式 などが挙げられる。しかし、これらの距離減衰式はどのサイトでも適応できるというわけではない。

そこで、対象サイトで地震観測を実施することにより得られる地点ごとの経験的な摇れやすさの傾向 を既往の距離減衰式に地点補正として取り込むことで、より精度の高い推定が可能となる。発電所など の重要施設で想定した断層による地震を対象に設計用の入力地震動を推定する場合にはこの方法がしば しば採用される。しかし、この方法は地震観測を実施した地点と地形や地質、地層構成などが同じ狭い 範囲に限られる。一方で、重要施設の中には送配電網や上下水道網、ガス配管網、鉄道などのように対 象構造物が広域に至り、複数の地形や地質の条件を有するインフラストラクチャもあるが、これらにつ いても同程度の精度で設計用の入力地震動を推定することが近年では求められている。一案として、構 造物が分布する領域内に地震計を密に設置する方法が挙げられるが、この手法は対象領域が広大な場合 には経済性の観点から、現実的ではない。

地震観測点が増加してきた昨今、観測記録を利用することで広域を対象とした地形や地域ごとの摇れ や寸さの傾向について研究が進められている。例えば、大西ら $(1999)^{6}$ は全国の気象庁地震観測点におけ る地形分類・表層地質と距離減衰式による地盤増幅度の関係を検討することにより、国土数值情報を利 用した最大加速度、最大速度、計測震度の地盤増幅度を推定した。野津ら $(2007)^{7}$ は強震記録に対してス ペクトルインバージョンを適用することで、工学的基盤より下方の深層地盤の影響を考慮したサイト増 幅特性を地震観測点ごとに評価し、各地域におけるサイト増幅特性の特徵について言及した。片岡ら $\left.(2008)^{8}\right)$ は日本全国の観測記録を基にやや長周期地震動を対象とした距離減衰式を作成し、地震観測点の 地点補正倍率を空間補間することにより全国における地点補正倍率を算定することで、任意の地点にお ける地震増幅特性を考慮した地震動強さを推定した。先名ら(2009) $)^{9}$ は微地形区分が判明している観測点 の常時微動観測記録の H/V スペクトル比を利用することで、各微地形区分に対応する地表の加速度応答 スペクトルを推定する手法を提案した。しかし、工学的基盤に着目した空間的な地震動の分布特性の検 討はほとんど行われていないのが実情である。

前述の課題を解決寸るにあたり、本研究では既に設置されている複数の地震観測点の記録を利用する ことで、工学的基盤面における摇れや寸さについて地理的・地形的条件や地質を踏まえたゾーニングを 実施し、その結果を基に工学的基盤面における加速度応答スペクトルの推定方法を提案する。工学的基 盤面を対象にした理由としては、設計用の地震動の多くが工学的基盤で設定されることを考慮したため である。ゾーニングの対象地域としては様々な地形と地質で形成され、複雑な地震動特性を呈する富士 山南東部地域を選定した。

\section{2. 工学的基盤面における摇れやすさのゾーニング}

\section{1 ゾーニング方法の概要}

地震動には震源特性、伝播経路特性、サイト特性の 3 つが大きく影響することが一般的に言われてい る。このうちサイト特性は地震基盤面より上にある堆積層による影響であるが、堆積層の種類や厚さは 場所によって大きく異なるため、摇れやすさの空間的な分析を実施する際にはこのサイト特性が含まれ ない地震基盤面で行うことが望ましい。しかし、例えば今回対象とする富士山南東部地域では、J-SHIS

（地震八ザードステーション）で公開されている深部地盤構造データと中央防災会議の「東南海、南海 地震等に関する専門委員会」で設定された深部地盤構造モデルが大きく異なることが確認できるように、 深部の速度構造を正確に把握することは難しい。一方で、地震基盤面より浅い工学的基盤面までの PS 検層などの情報に基づいた速度構造については、比較的に充実している。この様な背景と 1 章で述べた 目的より、本研究では地震基盤面はなく、速度構造が既知である工学的基盤面を対象にすることにした。 工学的基盤面に着目した際にはサイト特性として工学的基盤面と地震基盤面間の速度構造による影響が 含まれるが、空間的な分析を実施する範囲を限定した上で、本研究ではその影響も工学的基盤面におけ る摇れやすさの一因として含めた評価を行うことにした。その上で、工学的盤面における摇れやすさの 傾向について、地形や地質の分布を参考にゾーニングを実施した。工学的基盤面における摇れやすさの ゾーニング方法に関するフローを図 1 に示す。 


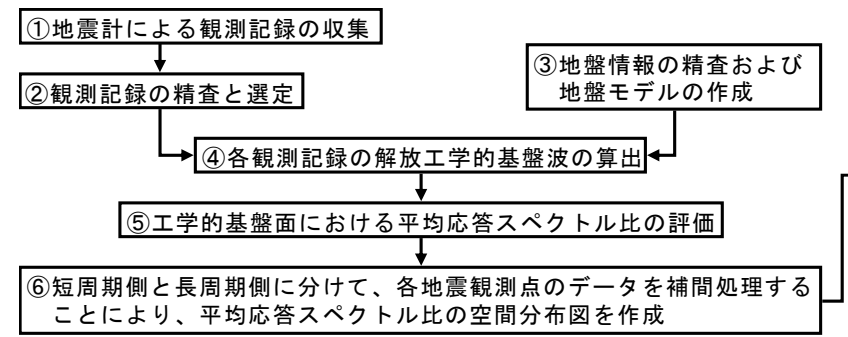

(7)次の段階を踏んでゾーニングを作成する。

1）(6)の空間分布図を基に、摇れやすさの特性だけで短周期側と長 周期側について個別に大まかなゾーニング。

）周期帯別の摇れやすさの指標（閾値）を設定し、その組み合わ せにより1)のゾーニングの領域を絞る。

-3）地形や地質の分布と比較し、マクロ的な観点から2)のゾーニン グ領域内で代表される地形・地質が支配的になるように領域を 絞る。この際に代表的な地形・地質以外にある局所的な特性を

有する領域に位置する地震観測点については除外する。

ことにより、平均応答スペクトル比の空間分布図を作成

）平均応答スペクトル比の全周期帯の形状が類似している地震観 測点だけになるように3)のゾーニングの領域をさらに絞る。

図 1 工学的基盤における摇れやすさのゾーニングのフロー

\section{2 地震観測記録の収集}

本研究では富士山南東部から伊豆半島北部一帯にある東京電力が保有寸る地震計と防災科学技術研究 所が保有する地震計（KiK-net と K-NET）の計 30 観測点における地震観測記録を使用した。地震観測地 点の分布を図 2 に示す。地震観測記録は基本的に地震計の観測開始時期から 2012 年 1 月 29 日までのデ ータのうち入手できたものを使用した。

\section{3 観測記録の精査と選定}

ノイズの影響が大きい地震観測記録についてはバンドパス処理を施し、 $\mathrm{S} / \mathrm{N}$ 比が良好でない地震観測 記録は除去するなどの精查を行った。また、観測記録の高周波数成分の品質について、地震計の精度に よる影響が以降の検討で使用寸る減衰 $5 \%$ の加速度応答スペクトルに現れていないことを確認した。精 查後の総地震数は 1090 になった。次に、分析に用いる地震観測記録の選定として、以下の 3 つ条件を 満たす地震による記録に限定した。なお、以降で取り扱うマグニチュードは一部例外を除きすべて気象 庁マグニチュードである。

(1) 気象庁マグニチュード $\left(M_{J}\right)$ が 5 以上

(2) 地震観測点から震源もしくは震源断層までの最短距離（R）が $200 \mathrm{~km}$ 以内

(3) 断層中心深さ $\left(H_{C}\right)$ が $100 \mathrm{~km}$ 以浅

この節で示す精査・選定に加え、後述の応答スペクトル比の精査を反映した結果、本研究の分析で対象 とする地震数は全地震観測点合わせて 105 となった。対象地震の震央分布図を図 3 に示し、その一覧を 表 1 に示す。

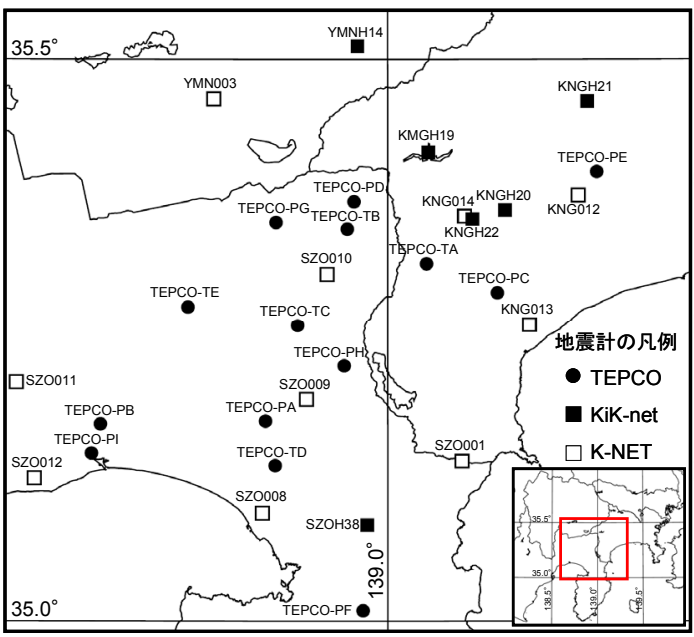

図 2 富士山南東部から伊豆半島北部一帯の 地震観測点の分布（計 30 地点）
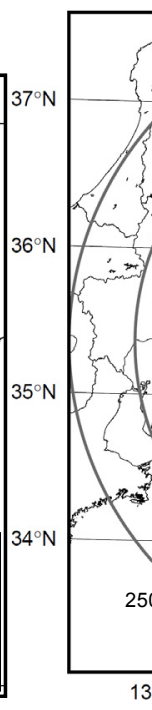

図 3 分析の対象にした地震の震央分布図 総地震数 : 105、O : 震央、色 : 深さ、中心 : TEPCO-PD 
表1＼cjkstart対象地震リスト

\begin{tabular}{|c|c|c|c|c|c|c|c|c|c|c|c|c|c|}
\hline \multirow{2}{*}{$\begin{array}{l}\text { 番 } \\
\text { 号 }\end{array}$} & \multicolumn{6}{|c|}{ 発生時刻 } & \multicolumn{4}{|c|}{$\begin{array}{l}\text { 震央位置 } \\
\text { 東経 }\end{array}$} & \multirow{2}{*}{$\begin{array}{c}\text { 深さ } \\
\mathrm{km}\end{array}$} & \multirow{2}{*}{$M_{\jmath}$} & \multirow{2}{*}{ 震源 } \\
\hline & 年 & 月 & & & & 秒 & 度 & & 度 & 経 & & & \\
\hline 1 & 1982 & $\frac{1}{8}$ & 12 & $\frac{13}{13}$ & 33 & 0.00 & $\frac{1 x}{34}$ & 53.00 & 139 & 34.00 & 30.00 & 5.7 & 相模灘 \\
\hline 2 & 1983 & 8 & 8 & 12 & 47 & 58.60 & 35 & 31.30 & 139 & 1.30 & 22.00 & 6.0 & 山梨県東部 \\
\hline 3 & 1984 & 2 & 14 & 1 & 53 & 0.80 & 35 & 35.30 & 139 & 6.20 & 25.00 & 5.4 & 山梨県東部 \\
\hline 4 & 1985 & 10 & & 21 & 25 & 51.60 & 35 & 52.30 & 140 & 9.30 & 78.04 & 6.0 & 茨城県南部 \\
\hline 5 & 1985 & 11 & 6 & & 30 & 50.00 & 35 & 21.50 & 140 & 14.20 & 62.09 & & 房総半島南部 \\
\hline 6 & 1986 & & & & 53 & 9.70 & 34 & 49.60 & 140 & 43.00 & 73.03 & 6.4 & 房総半島南東沖 \\
\hline 7 & 1986 & 12 & 30 & & 38 & 32.30 & 36 & 38.40 & 137 & 55.30 & 3.03 & 5.9 & 長野県北部 \\
\hline 8 & 1987 & 4 & 17 & 16 & 33 & 40.30 & 35 & 44.70 & 140 & 8.30 & 76.08 & 5.1 & 千葉県北部 \\
\hline 0 & 1987 & 12 & 17 & 11 & 8 & 16.80 & 35 & 22.50 & 140 & 29.60 & 57.09 & 6.7 & 九十九里沿岸付近 \\
\hline 10 & 1988 & 1 & 16 & 20 & 42 & 11.20 & 35 & 23.40 & 140 & 24.60 & 47.06 & 5.2 & 九十九里: \\
\hline 11 & 1988 & 3 & 18 & 5 & 34 & 29.40 & 35 & 39.90 & 139 & 38.60 & 96. & & \\
\hline 12 & 1988 & 8 & 12 & 14 & 14 & 53.90 & 35 & 5.90 & 139 & 51.80 & 69.04 & & 崖 \\
\hline 13 & 1988 & 9 & 5 & 0 & 49 & 22.40 & 35 & 30.00 & 138 & 59.00 & 29.06 & 5.6 & 山 \\
\hline 14 & 1988 & & 29 & 17 & 23 & 34.10 & 35 & 55.30 & 139 & 11.20 & 15.00 & & 䢐西 \\
\hline 15 & 1989 & 2 & 19 & 21 & 27 & 9.70 & 36 & 1.30 & 139 & 54.30 & 55.03 & 5.6 & 西部 \\
\hline 16 & 1990 & 8 & 5 & 16 & 13 & 2.10 & 35 & 12.60 & 139 & 5.50 & 13.06 & 5.3 & 箱根付近 \\
\hline 17 & 1991 & 9 & 3 & 17 & 44 & 47.40 & 33 & 41.20 & 138 & 49.70 & 33.01 & 6.3 & 三宅島近海 \\
\hline 18 & 1992 & 2 & 2 & 4 & 4 & 5.70 & 35 & 13.80 & 139 & 47.30 & 92.03 & 5.7 & 東京湾 \\
\hline 19 & 1993 & 5 & 21 & 11 & 36 & 37.90 & 36 & 2.70 & 139 & 53.80 & 60.08 & 5.4 & 茨城県南西部 \\
\hline 20 & 1996 & 3 & 6 & 23 & 35 & 28.72 & 35 & 28.55 & 138 & 56.86 & 19.59 & 5.5 & 山梨県東部 \\
\hline 21 & 1996 & 9 & 11 & 11 & 37 & 14.33 & 35 & 38.33 & 141 & 13.01 & 51.99 & 6.4 & 銚子付近 \\
\hline 22 & 1996 & 11 & 28 & 16 & 40 & 42.26 & 34 & 38.14 & 140 & 19.63 & 68.58 & 5.5 & 房総半島南東呮 \\
\hline 23 & 1996 & 12 & 21 & 10 & 28 & 47.71 & 36 & 5.77 & 139 & 51.65 & 53.11 & 5.6 & 茨城県南 \\
\hline 24 & 1997 & & & & 51 & 39.14 & 34 & 55.69 & 137 & 31.51 & 39.12 & & \\
\hline & 1997 & & 23 & & 58 & 55. & & 58.12 & 40 & & 71.46 & & \\
\hline & 1997 & 10 & 11 & 14 & 44 & 35.7 & & 25.62 & & 16.17 & 34 & & \\
\hline 2 & 1998 & 1 & 14 & 2 & 17 & 7.88 & 35 & 36.99 & 140 & 13.97 & 77.98 & 5.0 & $千$ \\
\hline 28 & 1998 & 8 & 29 & 8 & 46 & 42.35 & 35 & 37.98 & 140 & 1.76 & 64.60 & 5.3 & $T$ \\
\hline 20 & 1999 & 7 & 15 & 7 & 56 & 21.89 & 35 & 56.14 & 140 & 26.46 & 49.64 & 5. & 茨场 \\
\hline 30 & 1999 & 9 & 13 & 7 & 56 & 46.82 & 35 & 35.86 & 140 & 9.59 & 75.81 & 5.1 & 千葉県中部 \\
\hline 31 & 2000 & 6 & & 17 & 54 & 47.70 & 35 & 41.39 & 140 & 44.79 & 48.06 & 6. & 銚子付近 \\
\hline 32 & 2000 & 10 & 14 & & 19 & 39.54 & 34 & 6.45 & 140 & 31.13 & 86.53 & 5. & 房総半島南方 \\
\hline 33 & 2001 & & 23 & & 23 & 47.90 & 34 & 47.60 & 137 & 32.93 & 32.34 & 5 & 浜名做 \\
\hline 34 & 2001 & 4 & 3 & 23 & 57 & 12.43 & 35 & 1.45 & 138 & 5.66 & 30.34 & 5 & 静岡県中部 \\
\hline 35 & 2001 & 6 & & 0 & 41 & 45. & & 59.67 & & 6.45 & 30 & $5.6>-1$ & 静岡 \\
\hline 36 & 2001 & 7 & 20 & 6 & 2 & 36. & 36 & & & 48.75 & 55.17 & & 茨城県南 \\
\hline 37 & 2002 & 6 & 14 & 11 & 42 & 49.3 & 36 & 12.98 & 139 & 58.63 & & & 茨城県南西部 \\
\hline & 2003 & 3 & 13 & 12 & 12 & 58.0 & & 5.41 & & 51.34 & 47.26 & & 茨坞 \\
\hline & 2003 & 5 & 12 & 0 & 57 & 6. & & 52.13 & 40 & 5.14 & 46 & & \\
\hline 4 & 2003 & 5 & 17 & 23 & 33 & 10. & 3 & 44.31 & 40 & 39.04 & 47 & & \\
\hline 4 & 2003 & 9 & 20 & 12 & 54 & 52. & 3 & 13.13 & 40 & 18.02 & $69>->$ & $5.8>->$ & 沿 \\
\hline $42>>$ & 2003 & 10 & 15 & 16 & 30 & 35 & & 36.82 & 40 & 2 & $73 \mathrm{~S}=2$ & & \\
\hline 4 & 2003 & 11 & 23 & 7 & 0 & 20 & & 34.50 & 141 & & 39 & & \\
\hline & 2004 & 7 & 17 & 15 & 10 & & & 50 & 40 & 21 & & & 房 \\
\hline 45 & 2004 & 10 & 6 & 23 & 40 & & 2 & 59.33 & 140 & & & & \\
\hline 46 & 2004 & 10 & 23 & 17 & 56 & & & & 138 & 52.03 & & & \\
\hline 47 & 2004 & 10 & 23 & 18 & 11 & 56 & 37 & 15.18 & 138 & 49.77 & $\begin{array}{l}11.58 \\
11.52\end{array}$ & $6 . c+2>$ & \\
\hline 48 & 2004 & 10 & 23 & 18 & 34 & 5.69 & 37 & 18.38 & 138 & 55.80 & 14.17 & 6.5 & 新渴県中部 \\
\hline $4 !$ & 2004 & 10 & 27 & 10 & 40 & 50.24 & 37 & 17.51 & 139 & 2.00 & 11.60 & & 新潟県中部 \\
\hline 50 & 2004 & 11 & 9 & 0 & 7 & 25.14 & 33 & 47.26 & 138 & 24.62 & 51.22 & & 東海地方南方 \\
\hline 5 & 2005 & 2 & 16 & 4 & 46 & 36.13 & 36 & 231 & 139 & 53.33 & 46.15 & 5.3 & 茨城県南西部 \\
\hline & 2000 & 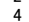 & 0 & & & 15.63 & 0 & 43.61 & 140 & 3727 & 51 & 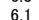 & \\
\hline 53 & 2005 & & & & 14 & 26.28 & 35 & 33.56 & 141 & 4.92 & 33.35 & & 銚 \\
\hline
\end{tabular}

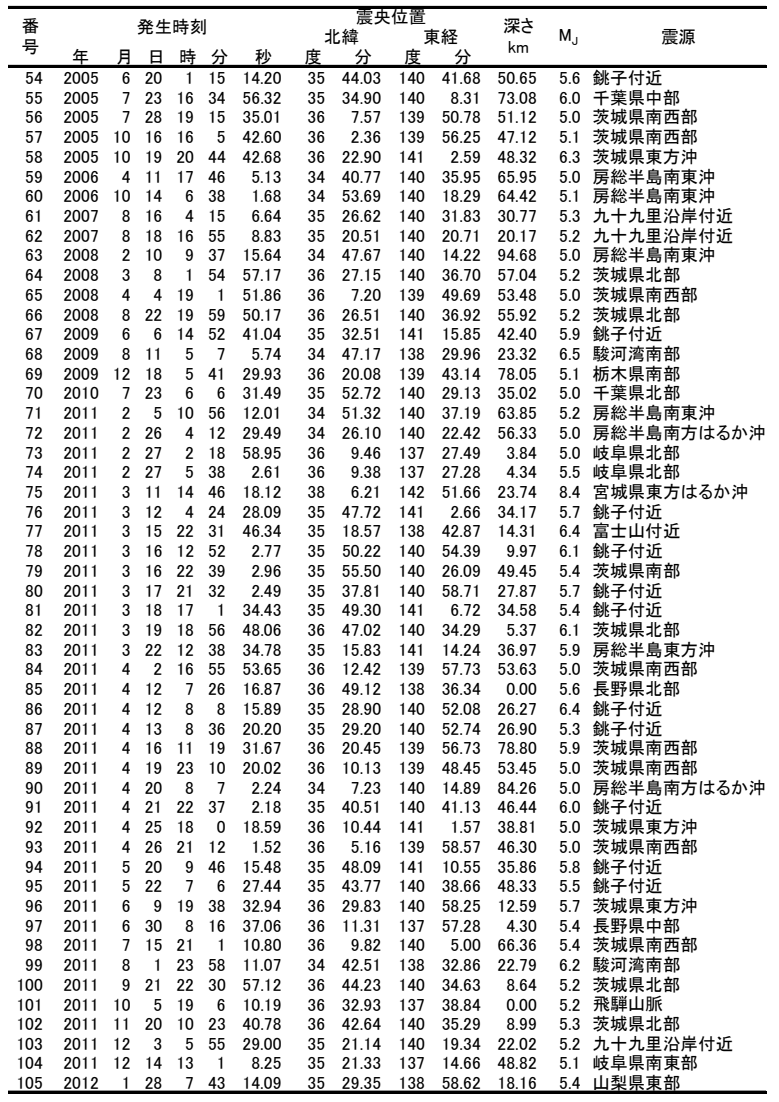

\section{4 地盤情報の精査および地盤モデルの作成}

各地震観測点の地盤調查結果のデータを精查し、地盤モデルを作成した。鉛直アレイを実施している 地震観測点のうち東京電力が所有する8地点 (TEPCO-PA、TEPCO-PC、TEPCO-PD、TEPCO-PE、TEPCO-PF、 TEPCO-PG、TEPCO-PH、TEPCO-PI）については観測記録のS波主要動のフーリエスペクトル比（地表 フーリエスペクトル／地中フーリエスペクトル）をターゲットにS波速度と減衰の逆解析を実施し、弱 震動用と強震動用の最適地盤モデルを同定した。実施した逆解析は1次元のSH波の鉛直入射に基づき、 探索範囲はPS検層の結果の土数 $10 \%$ 程度とした。また、層厚は地盤調査結果で得られた值で固定し、減 衰は周波数依存性を考慮した。逆解析手法としては、処理を行った時期によりべーズ法 ${ }^{10}$ を用いた地点 と遺伝的アルゴリズムを用いた地点がある。逆解析手法の違いの影響がほとんど無いことは事前に確認 している。弱震動用の最適地盤モデルは地表最大加速度が $100 \mathrm{~cm} / \mathrm{sec}^{2}$ 未満の弱震動記録の平均スペクト ル比から同定した。地表最大加速度が $100 \mathrm{~cm} / \mathrm{sec}^{2}$ 以上を示寸地震記録はフーリエスペクトル比を弱震動 のものと比較し、ピークが低周波数側に移動している場合は地盤の非線形性が現れていると判断した。 地盤の非線形性が確認された地震記録は、地震ごとに強震動用の最適地盤モデルを作成した。逆解析結 果の一例として、観測記録の平均フーリエスペクトル比と弱震動用最適地盤モデルの伝達関数の比較を 図4に示す。地表記録しかない地震観測点やKiK-netの地震観測点についてはPS検層の結果に基づいて地 盤モデルを作成した。このような地震観測点については、観測記録より表層地盤における増幅の影響が 取り除かれていることを確認している。作成した地盤モデルの一例を表2に示す。

\section{5 各観測記録の工学的基盤波解放工学的基盤波の算出}

一次元波動論に基づく引戻し剝取り計算により、作成した弱震動用および強震動用の地盤モデルを用 いて精查後の地震観測記録のうち地表の水平成分のから観測記録から工学的基盤の波形解放工学的基盤 波（2E）を算出した。なお、解放工学的基盤波の算出ではP波からコーダ波までの波形全体を使用して いる。次節以降で使用する推定式の適用範囲に合わせて、工学的基盤はS波速度の值が $300 \sim 600 \mathrm{~m} / \mathrm{sec}$ 程 
度に相当する層に設定した。ただし、対象となる層がない地震観測点については、直上の層と比較して S波速度インピーダンス比が十分に大きい層を工学的基盤に設定した。各地震観測点で設定した工学的 基盤のS波速度を表3にまとめる。多くの地震観測点における工学的基盤のS波速度の大きさは推定式の 適用範囲であるが、そうではない地震観測点もある。このような地震観測点において工学的基盤におけ るS波速度の大きさが次節以降の検討に対して大きく影響しないことは確認している。
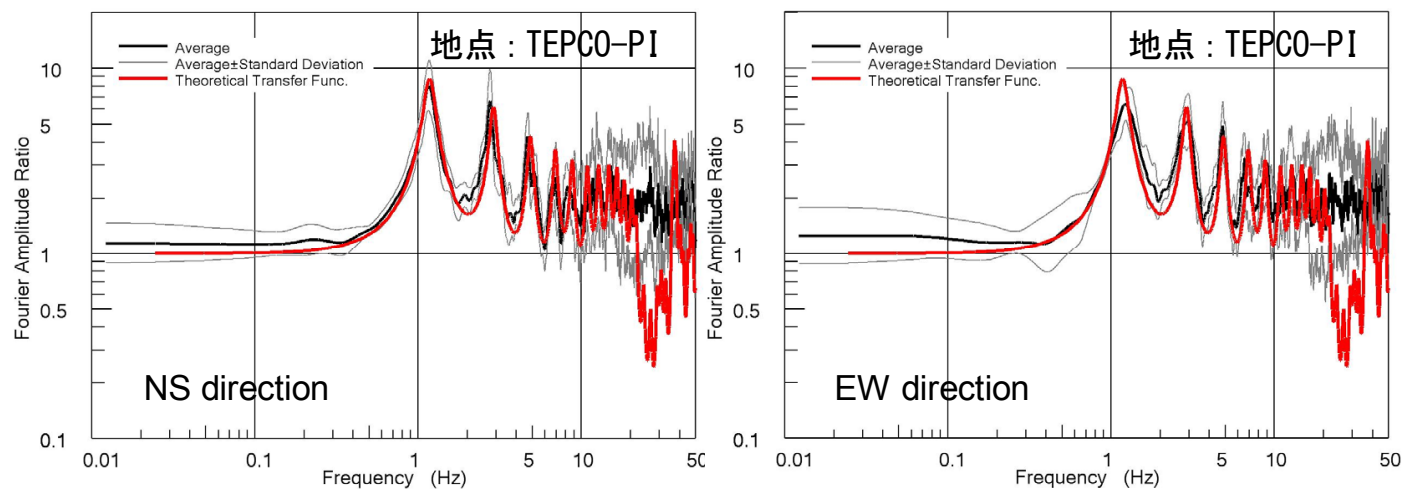

図 4 観測記録の平均フーリエスペクトル比と弱震動用最適地盤モデルの伝達関数の比較

表2＼cjkstart地盤モデルの一例

\begin{tabular}{|c|c|c|c|c|c|}
\hline $\begin{array}{l}\text { 層 } \\
\text { 番号 }\end{array}$ & $\begin{array}{c}\text { 層厚 } \\
(\mathrm{m})\end{array}$ & 土質 & $\begin{array}{c}\text { 密度 } \\
\left(t / m^{3}\right)\end{array}$ & $\begin{array}{l}\text { S波速度 } \\
(\mathrm{m} / \mathrm{sec})\end{array}$ & 減衰 \\
\hline & 9.00 & 表土、凝灰岩 & 1.90 & 120 & 02 \\
\hline 工学 & 基盤 & 凝灰岩、磁岩 & 1.90 & 600 & 102 \\
\hline
\end{tabular}

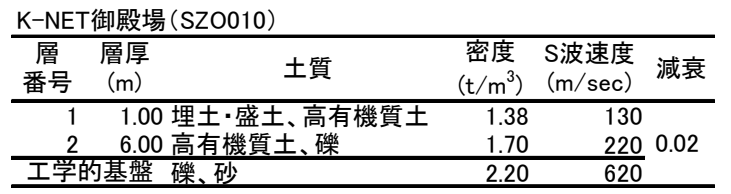

表 3 設定した工学的基盤の $S$ 波速度一覧

\begin{tabular}{ccc} 
TEPCO & & \\
\hline 地震 & 工学的基盤の & 判断 \\
観測点名 & S波速度 $(\mathrm{m} / \mathrm{sec})$ & 基準 \\
\hline TEPCO-PA & 617 & $\mathrm{~A}$ \\
TEPCO-PB & 420 & $\mathrm{C}$ \\
TEPCO-PC & 518 & $\mathrm{~A}$ \\
TEPCO-PD & $(\mathrm{X}) 823(\mathrm{Y}) 778$ & $\mathrm{~B}$ \\
TEPCO-PE & $(\mathrm{X}) 577(\mathrm{Y}) 572$ & $\mathrm{~A}$ \\
TEPCO-PF & 447 & $\mathrm{~A}$ \\
TEPCO-PG & $(\mathrm{X}) 656(\mathrm{Y}) 685$ & $\mathrm{~A}$ \\
TEPCO-PH & $(\mathrm{X}) 918(\mathrm{Y}) 905$ & $\mathrm{~B}$ \\
TEPCO-PI & 1175 & $\mathrm{~B}$ \\
TEPCO-TA & 323 & $\mathrm{~A}$ \\
TEPCO-TB & 385 & $\mathrm{~A}$ \\
TEPCO-TC & 410 & $\mathrm{~A}$ \\
TEPCO-TD & 370 & $\mathrm{~A}$ \\
TEPCO-TE & 1730 & $\mathrm{C}$ \\
\hline
\end{tabular}

\begin{tabular}{ccc} 
KiK-net & & \\
\hline 地震 & 工学的基盤の & 判断 \\
観測点名 & S波速度 $(\mathrm{m} / \mathrm{sec})$ & 基準 \\
\hline KNGH19 & 700 & $\mathrm{~B}$ \\
$\mathrm{KNGH} 20$ & 600 & $\mathrm{~A}$ \\
$\mathrm{KNGH} 21$ & 1400 & $\mathrm{~B}$ \\
$\mathrm{KNGH} 22$ & 490 & $\mathrm{~A}$ \\
$\mathrm{SZOH} 38$ & 580 & $\mathrm{~A}$ \\
$\mathrm{YMNH} 14$ & 800 & $\mathrm{~B}$ \\
\hline
\end{tabular}

\begin{tabular}{|c|c|c|}
\hline \multicolumn{3}{|l|}{ K-NET } \\
\hline 地震 & 工学的基盤の & 判断 \\
\hline 観測点名 & $\mathrm{S}$ 波速度 $(\mathrm{m} / \mathrm{sec})$ & 基準 \\
\hline KNG012 & 630 & $A$ \\
\hline KNG013 & 250 & $B$ \\
\hline KNG014 & 445 & A \\
\hline SZO001 & 435 & A \\
\hline SZO008 & 450 & A \\
\hline SZOO009 & 690 & $A$ \\
\hline SZO010 & 620 & A \\
\hline SZO011 & 460 & $A$ \\
\hline SZO012 & 400 & $A$ \\
\hline YMN003 & 740 & $B$ \\
\hline 㳊 & & \\
\hline$x$ & 層 & 層 \\
\hline
\end{tabular}

\section{6 工学的基盤面における平均応答スペクトル比の評価}

観測地点ごとに、2.3 節で選定した地震観測記録から応答スペクトル比を算定する。ここでいう応答スペ クトル比とは、観測記録による解放工学的基盤波から算定される加速度応答スペクトルと、工学的基盤面に おける加速度応答スペクトル推定式（距離減衰式）との比を意味する。なお加速度応答スペクトルの減衰の 大きさは、推定式の減衰に統一寸ることに注意する。本研究中では、工学的基盤の加速度応答スペクトル推 定式の一例として、関東地方の工学的基盤のデータに基づき作成された Annaka and Nozawa $(1988)^{11)}$ を使用 する。この推定式は関東地域の $\mathrm{S}$ 波速度 300 600 $\mathrm{m} / \mathrm{sec}$ 程度の工学的基盤における地震動を推定する式 として設定されている。推定式は Annaka and Nozawa (1988)以外の Kanno et al (2006) ${ }^{12)}$ や NGA プロジェ クト ${ }^{13)}$ の距離減衰式の一部などでも適用可能であり、この評価方法は汎用性を有する。

推定式に用いる震源パラメータは以下の条件で設定した。 
(1) 震源断層モデルが作成されている地震は震源断層モデルのパラメータを使用（表 4 参照）

(2) (1)以外の 2010 年 9 月までの地震は「地震・火山月報（カタログ編） 2010 年 9 月」を使用

(3) (1)(2)以外の地震は Hi-net で公開されている「気象庁一元化処理 震源リス卜 (2012 年 2 月 21 日時点)」を使用

表 4 震源断層モデルを使用する地震一覧

\begin{tabular}{|c|c|c|c|c|c|c|c|c|c|c|c|c|c|c|}
\hline \multirow{2}{*}{$\begin{array}{c}\text { 断層 } \\
\text { モデル }\end{array}$} & \multirow{2}{*}{\multicolumn{6}{|c|}{ 発生時刻 }} & \multicolumn{4}{|c|}{ 震央位置 } & \multirow{2}{*}{$\begin{array}{c}\text { 深さ } \\
\text { km }\end{array}$} & \multirow[b]{2}{*}{$M_{J}$} & \multirow[b]{2}{*}{ 震源地 } & \multirow[b]{2}{*}{ 参考文献 } \\
\hline & & & & & & & & 緯 & & 経 & & & & \\
\hline 1 & 1978 & 6 & 12 & 17 & 14 & 2540 & 38 & 900 & 142 & 1000 & (400ก & 74 & 宮城䢐東方 & $980)^{14)}$ \\
\hline 2 & 1982 & 7 & 23 & 23 & 23 & 50.90 & 36 & 11.00 & 141 & 57.00 & 30.00 & 7.0 & 茨城県東方遠沖 & 菊池·須藤(1985) ${ }^{15)}$ \\
\hline 3 & 1987 & 12 & 17 & 11 & 8 & 16.80 & 35 & 22.50 & 140 & 29.60 & 57.09 & 6.7 & 房総半島九十九里浜 & 岡田·笠原(1988) ${ }^{16)}$ \\
\hline 4 & 1990 & 2 & 20 & 15 & 53 & 39.80 & 34 & 45.80 & 139 & 13.80 & 5.08 & 6.5 & 伊豆·大島付近 & 望月·大林(1990) $)^{17)}$ \\
\hline 5 & 2003 & 5 & 26 & 18 & 24 & 33.42 & 38 & 49.26 & 141 & 39.04 & 72.03 & 7.1 & 宮城県北部 & 浅野·他(2004) ${ }^{18)}$ \\
\hline 6 & 2003 & 9 & 26 & 4 & 50 & 7.42 & 41 & 46.71 & 144 & 4.71 & 45.07 & 8.0 & 東海南東方 & 国土地理院 ${ }^{19)}$ \\
\hline 7 & 2004 & 9 & 5 & 19 & 7 & 7.50 & 33 & 1.99 & 136 & 47.86 & 37.58 & 7.1 & 紀伊半島南東方 & 山中 ${ }^{20)}$ \\
\hline 8 & 2004 & 9 & 5 & 23 & 57 & 16.81 & 33 & 8.25 & 137 & 8.48 & 43.54 & 7.4 & 紀伊半島南東方 & 国土地理院 $^{21)}$ \\
\hline 9 & 2004 & 9 & 7 & 8 & 29 & 36.27 & 33 & 12.55 & 137 & 17.57 & 40.98 & 6.5 & 紀伊半島南東方 & 山中 ${ }^{20)}$ \\
\hline 10 & 2004 & 10 & 23 & 17 & 56 & 0.30 & 37 & 17.55 & 138 & 52.03 & 13.08 & 6.8 & 新潟県中部 & Hikima and Koketsu(2005) ${ }^{22)}$ \\
\hline 11 & 2004 & 10 & 23 & 18 & 34 & 5.69 & 37 & 18.38 & 138 & 55.80 & 14.17 & 6.5 & 新潟県中部 & Hikima and Koketsu(2005) \\
\hline 12 & 2004 & 10 & 27 & 10 & 40 & 50.24 & 37 & 17.51 & 139 & 2.00 & 11.60 & 6.1 & 新潟県中部 & 東大地震研 $^{23)}$ \\
\hline 13 & 2005 & 8 & 16 & 11 & 46 & 25.74 & 38 & 8.97 & 142 & 16.67 & 42.04 & 7.2 & 宮城県東方 & 国土地理院 $^{24)}$ \\
\hline 14 & 2007 & 3 & 25 & 9 & 41 & 57.91 & 37 & 13.24 & 136 & 41.16 & 10.70 & 6.9 & 能登半島沖 & 国土地理院 $^{25)}$ \\
\hline 15 & 2007 & 7 & 16 & 10 & 13 & 22.55 & 37 & 33.41 & 138 & 36.57 & 16.75 & 6.8 & 新潟県南方 & 国土地理院 $^{26)}$ \\
\hline 16 & 2008 & 5 & 8 & 1 & 45 & 18.77 & 36 & 13.69 & 141 & 36.46 & 50.57 & 7.0 & 茨城県東方遠沖 & 山中 27$)$ \\
\hline 17 & 2009 & 8 & 11 & 5 & 7 & 5.74 & 34 & 47.17 & 138 & 29.96 & 23.32 & 6.5 & 駿河湾南部 & 国土地理院 ${ }^{28)}$ \\
\hline 18 & 2011 & 3 & 11 & 14 & 46 & 18.12 & 38 & 6.21 & 142 & 51.66 & 23.74 & 8.4 & 宮城県東方遠沖 & 気象庁·気象研究所 ${ }^{29)}$ \\
\hline 19 & 2011 & 3 & 15 & 22 & 31 & 46.34 & 35 & 18.57 & 138 & 42.87 & 14.31 & 6.4 & 富士山地区 & 国土地理院 ${ }^{30)}$ \\
\hline 20 & 2011 & 4 & 7 & 23 & 32 & 43.46 & 38 & 12.25 & 141 & 55.21 & 65.89 & 7.1 & 宮城県東方 & 国土地理院 $^{31)}$ \\
\hline 21 & 2011 & 4 & 12 & 8 & 8 & 15.89 & 35 & 28.90 & 140 & 52.08 & 26.27 & 6.4 & 千葉県銚子市付近 & 国土地理院 ${ }^{32)}$ \\
\hline
\end{tabular}

算出した応答スペクトル比のうち、全体の傾向から大きく外れるものについては、サイトの地盤の特 徵ではなく地震の震源に起因するものであるから除去した。その一例として K-NET 御殿場（SZO010） で収集した地震記録のうち 2.3 節に示寸条件を満た寸地震の応答スペクトル比の分布を図 5 に、その震 央分布図を図 6 にそれぞれ示す。図 5 に示している応答スペクトル比のうち緑線は伊東沖や伊豆諸島周 辺を震源とした浅い火山性の地震、赤線は 2005 年 4 月 11 日に銚子付近の太平洋プレートとフィリピン 海プレートの境界で発生した逆断層型の地震（ $\mathrm{M}_{\mathrm{j}} 6.1 ）$ である。これらの地震は他の地震（図 5 の青線） と比較して応答スペクトル比が系統的に小さく、この傾向は他の地震観測点の多くでも現われている。 後者の銚子付近で発生した地震については、近傍で同規模の地震が多発しているが、今回の対象地域に おいてこの傾向が顕著に現われるのは当該地震のみである。精査後の応答スペクトル比の幾何平均値を 対象の地震観測地点の平均応答スペクトル比とし、摇れやすさを評価する際の指標とした。その一例と して K-NET 御殿場（SZO010）の結果を図 7 および図 8 の青線で示す。図 7 には、断層中心深さによる 違いを確認するために、各断層中心深さ別 $\left(0 \leqq H_{C} \leqq 30 \mathrm{~km} 、 30<H_{C} \leqq 60 \mathrm{~km} 、 60<H_{C} \leqq 100 \mathrm{~km}\right)$ の結果 もそれぞれ赤線、橙線、緑線で示す。なお、青線は断層中心深さ $0 \leqq H_{C} \leqq 100 \mathrm{~km}$ とした場合の結果であ る。60km より深い地震（栃木県南部や茨城県南部、千葉県中部、房総半島南東沖で発生したプレート 間の地震) の平均応答スペクトル比は、短周期側で他の浅い地震と比べて大きくなることが図 7 より確 認でき、K-NET 御殿場（SZO010）ではプレート間地震の影響が見られるが、本研究ではこの程度の差 は伊東沖や伊豆諸島周辺の浅い火山性の地震のばらつきと比べて十分小さく、ばらつきの範囲内である と判断した。また、図 8 には推定式による違いを確認するために、Kanno et al (2006)による結果を赤線 で示す。Kanno et al (2006)による平均応答スペクトル比を算出する際には、モーメントマグニチュード の值の決め方などは基本的に元の文献と同じ条件に合わせた。しかし、2 つの推定式による結果を比較 するための条件を合わせるために、(1) 対象にする地震は本研究の選定条件に合わせること、(2) 地表観 測記録ではなく解放工学的基盤波を使用寸ることという 2 つの条件については変更を加えた。後者(2)の 条件については、工学的基盤以下の AVS30 を算定し Kanno et al (2006)の AVS30 による地点補正項に代 
入することで、平均応答スペクトル比の評価位置を工学的基盤に合わせた。また、Kanno et al (2006)で は震源の深さによって推定式を分けているので、各地震に対する応答スペクトル比を算出する際には震 源の深さに対応した推定式を使用したが、平均応答スペクトル比を算出する際には震源の深さで分ける ことをせず、すべての結果の幾何平均值とした。図 8 において、2 つの推定式による平均応答スペクト ル比が一致しないのは推定式が異なるためだが、観測記録による解放工学的基盤波が推定式に比べて短 周期側では比較的に小さく、長周期側で大きくなるという傾向は 2 つ推定式で一致していることが確 認できる。また、ピークが現れる周期も 2 つ推定式間では差異がないことも確認できる。

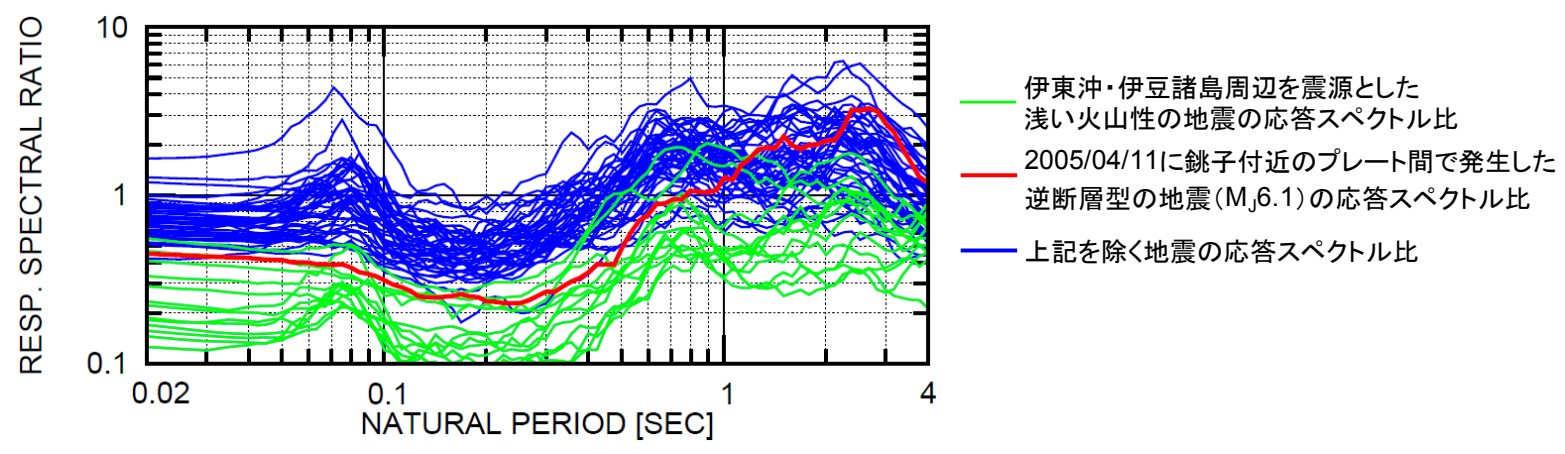

図 5 K-NET 御殿場 (SZ0010) の応答スペクトル比の分布

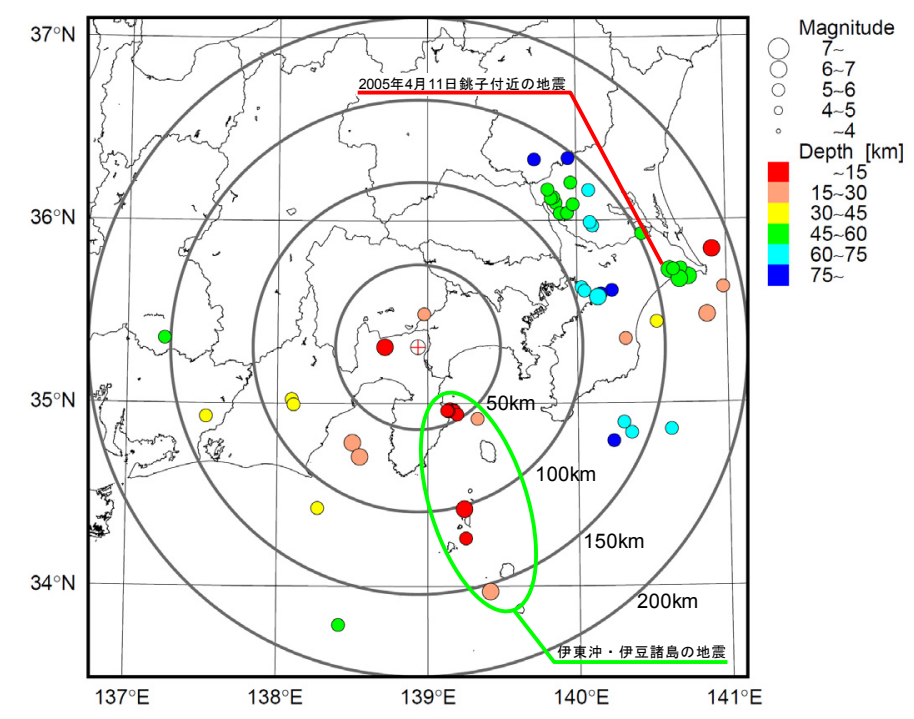

図 6 K-NET 御殿場 (SZ0010) で収集した地震観測記録の震央分布図 $\left(M_{J} \geqq 5 、 H_{c} \leqq 100 \mathrm{~km} 、 R \leqq 200 \mathrm{~km}\right)$ O : 震央、色 : 深さ、中心 : SZ0010

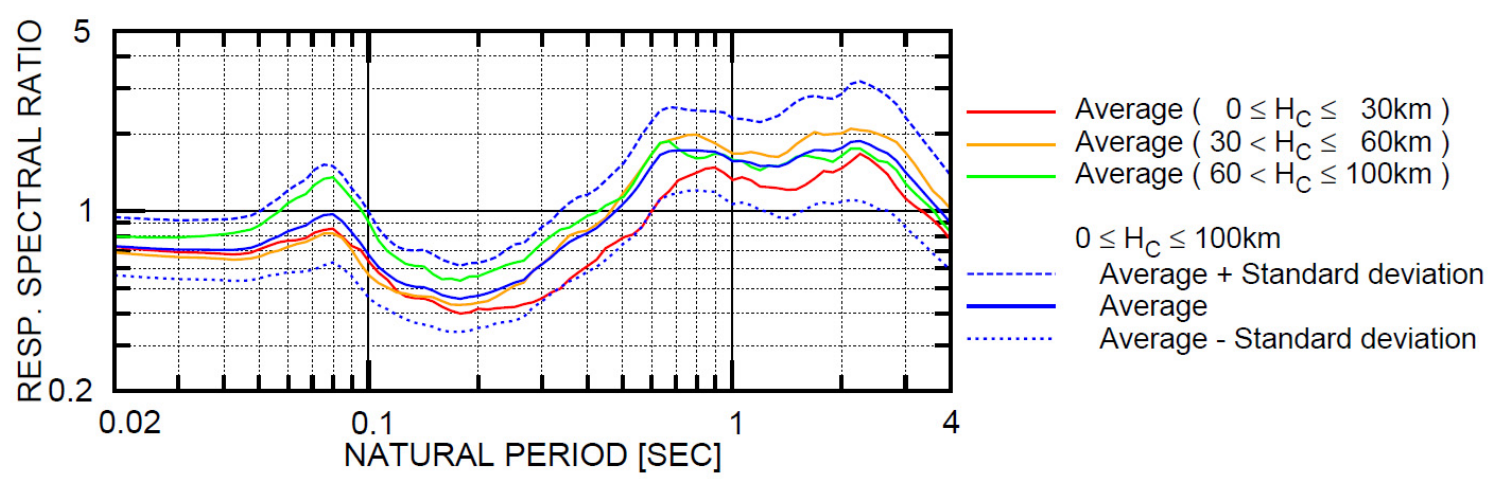

図 7 K-NET 御殿場 (SZ0010)の平均応答スペクトル比（断層中心深さによる違い） 


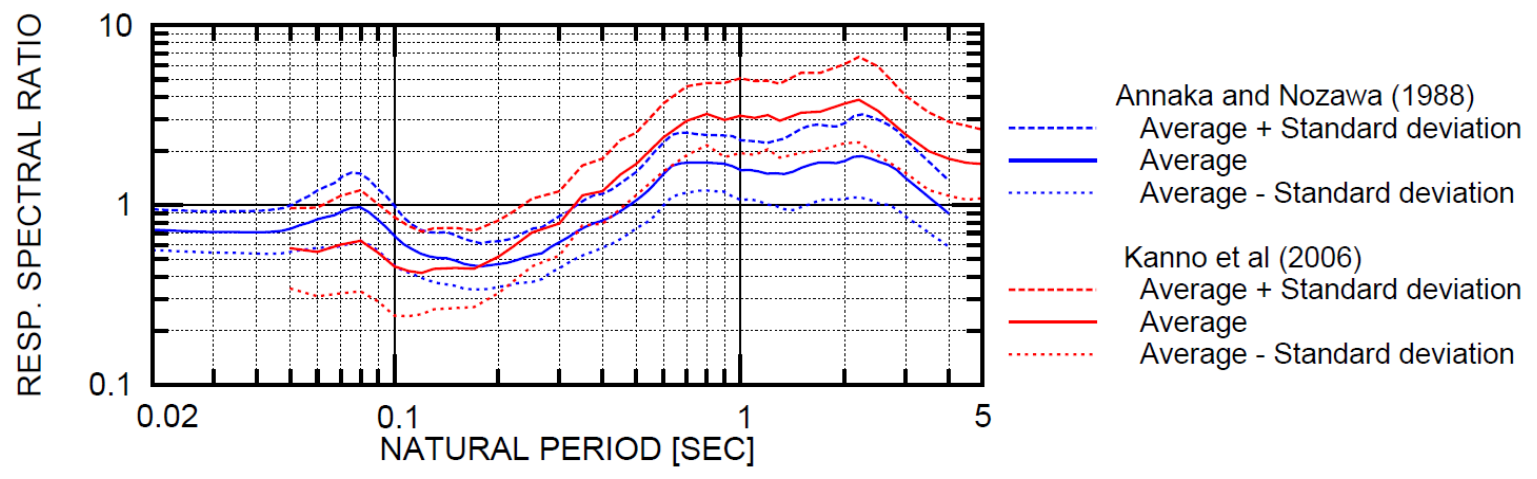

図 8 K-NET 御殿場 (SZ0010) の平均応答スペクトル比（推定式による違い)

Annaka and Nozawa (1988)による 30 観測点の平均応答スペクトル比の空間的な分布を図 9 に示す。図 9 より、工学的基盤面において地震動は決して一様ではなく、地域で特性が異なっていることが確認で きる。例えば、図の北東側（神奈川県の内陸側周辺）の地震観測点の多くでは平均応答スペクトル比が 全体的に 1 より小さく、特に長周期側の平均応答スペクトル比が 1 を大きく下回る傾向が見られる。一 方で、その地域の少し南東側に位置する地域（神奈川県の海側周辺や神奈川県一静岡県一山梨県の県境 付近）の地震観測点の多くでは平均応答スペクトル比が全体的に 1 に近く、また短周期側よりも長周期 側の平均応答スペクトル比の方が大きくなる傾向を持つ地震観測地点が複数存在する。

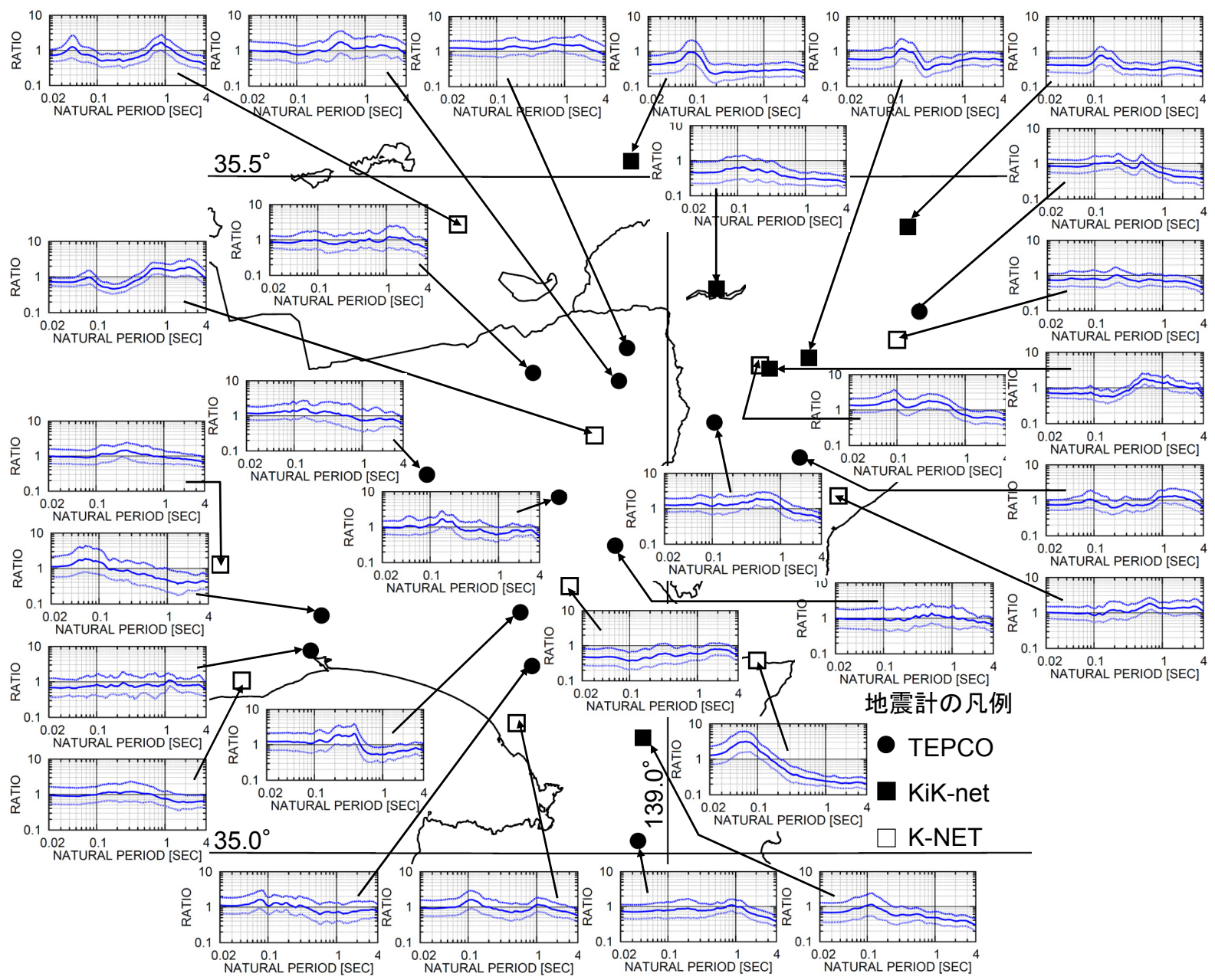

図9 30観測点の平均応答スペクトル比の分布図（グラフの縦軸のRATIOは応答スペクトル比を示す） 


\section{7 平均応答スペクトル比の空間分布による評価}

図9に示すような地震観測地点のみの平均応答スペクトル比の分布図のままでは空間的な評価が困難 である。そこで、全地震観測点の平均応答スペクトル比を補間処理して空間的な分布を求めた。空間補 間の手法には塩野ら $(1988)^{33)}$ の手法を使用した。観測点は空間的に不規則に分布するため、データを非 線形最小二乗法により空間補間として格子状のデータとした。二次元平面空間における $N_{x} \times N_{y}$ 個の格子 データを未知変数 $\mathbf{f}=\left\{f_{11}, f_{12}, \cdots f_{N_{x} \times N_{y}}\right\}$ と表すと、最適化問題の目的関数は次式の通りとなる。

$$
J(\mathbf{f})=w_{1} \cdot J_{1}(\mathbf{f})+w_{2} \cdot J_{2}(\mathbf{f})
$$

ここで、 $J_{1}(\mathbf{f})$ : 隣接格子間の差（1次の導関数）のノルム、 $J_{2}(\mathbf{f})$ : 隣接格子間の差の変化量（2次の導 関数）のノルム、 $w_{1}$ と $w_{2}$ は重み係数を表す。式(1)は離散化データf る。式(1)の目的関数を次式の制約条件の下で最適解を求めることにより、滑らかな格子状の補間データ が得られる。式(2)は線形補間を利用して、観測值を対応する格子セル4隅の格子点で近似している。

$\left(1-\varepsilon_{k}\right)\left(1-\eta_{k}\right) \cdot f_{i(k), j(k)}+\left(1-\varepsilon_{k}\right) \cdot \eta_{k} \cdot f_{i(k), j(k)+1}+\varepsilon_{k} \cdot\left(1-\eta_{k}\right) \cdot f_{i(k)+1, j(k)}+\varepsilon_{k} \cdot \eta_{k} \cdot f_{i(k)+1, j(k)+1}=z_{k} \quad(k=1,2, \cdots, N)$

ここで、 $z_{k}$ は観測值である。なお、 $x$ 軸方向と $y$ 軸方向の格子の刻みを、それぞれ $\Delta x 、 \Delta y$ とすると、 $\varepsilon_{k}=\left(x_{k}-x_{i(k)}\right) / \Delta x 、 \eta_{k}=\left(y_{k}-y_{i(k)}\right) / \Delta y$ である。また、 $i$ と $j$ は格子番号を表す。

空間補間に用いる代表値には図10に示寸ように平均応答スペクトル比のうち、短周期側の成分につい ては固有周期の範囲が 0.02 秒以上 0.2 秒以下、長周期側の成分ついては 0.7 秒以上 2.0 秒以下の幾何平均值を 使用した。これらの範囲は後に比較する地形や地質の分布と比較する際に最も特徵を掴みや寸くなるよ うに決定した。以上の結果を図11に示す。空間分布のコンター図の境界值は昇順（すなわち、青 $\rightarrow$ 赤に かけて）に $10^{-0.3} 、 10^{-0.2} 、 10^{-0.1} 、 10^{0} 、 10^{0.1} 、 10^{0.2} 、 10^{0.3}$ (実数表示では $0.501 、 0.631 、 0.794 、 1.000 、 1.259 、$ 1.585、1.995）と設定した。本研究では空間分布図中でこの值が大きい地域の工学的基盤は摇れやすく、 小さい地域の工学的基盤は摇れにくいと判断した。

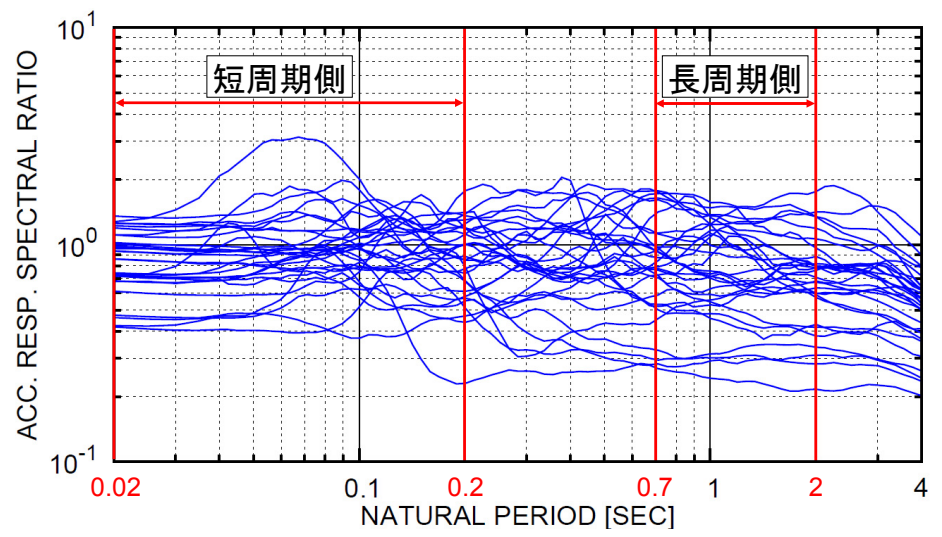

図10＼cjkstart全観測地点の平均スペクトル比の重ね描きと短周期側と長周期側の範囲

平均応答スペクトル比の空間分布図（図11）と地形の分布との対応を比較するための参考資料として 地形分類図 ${ }^{34)}$ を図12に示す。長周期側に関しては、(6)丹沢山地、(5)箱根山および(1)愛鷹山など山地や火 山地では平均応答スペクトル比が小さくなり、(8)足柄平野から (3)小山町周辺にかけては大きくなる傾向 が見られ、地形の分布との対応が良い。短周期側に関しては、(5)箱根山および1)愛鷹山の火山地では平 均応答スペクトル比が大きくなり、(5)箱根山と(1)愛鷹山の間の火山山麓地や(6)丹沢山地では小さくなる 傾向が見られるが、長周期側ほど地形の分布とは対応していない。一般に新第三紀以前に形成された山 地は摇れにくく、第四紀以降の堆積物で構成される平野は摇れや寸い傾向であることは、1章で紹介して いる既往の研究（大西ら(1999)、野津ら(2007)、片岡ら(2008)、先名ら(2009)）の結果でも示されている が、本研究での結果もこれに当てはまるといえる。一方で山地や平野のような明確に判断できる地形以 
外については、地域ごとに摇れやすさの特性が異なる可能性が考えられるため、地域を考慮せず地形だ けで摇れや寸さの特性を一概に定義してしまうのは好ましくない。例えば、丘陵は地名に「丘陵」とい う単語が含まれていたとしても一般的な定義（約 $300 \mathrm{~m}$ 以下の山地より小規模な起伏）と一致しない場合 がある。これは丘陵の詳細な定義に地域差があるためである。同様のことが台地・段丘、盆地・谷底低 地にもいえる。また、大西ら(1999)は距離減衰式の補正項として導入した全国の地震観測点ごとの摇れ やすさを表す係数と地形分類の関係を分析しているが、台地・段丘では特にばらつきが大きく、地形だ けではなく地質条件を含めた分類が必要であることを示している。

地域ごとの摇れや寸さの傾向としては、(1)愛鷹山周辺や(5)箱根から熱海周辺の火山帯では短周期で摇 れやすく、長周期で摇れにくい。(6)丹沢山地周辺は周期に関係なく摇れにくい。これらは地形の分布と の対応が良い。一方、(3)小山町周辺は周期に関係なく摇れや寸いが、地形の分布との対応だけでは説明 が難しい。

次に、地質の分布との対応を比較するための参考資料として関東地方土木地質図 ${ }^{35}$ を図13に示す。地 質に関しては周期帯に関係なく地形の分布ほどの対応が認められない。特に長周期側に着目すると、「降 下火山灰およびスコリアなど」の地質（bt2、bt1、at1）を有する地域のうち、北東側は平均応答スペク トル比が大きいのに対し、南西側は小さくなる傾向が見られ、同じ系統の地質であっても摇れやすさの 傾向が異なる。一方で、大西ら(1999)の研究では地形よりも表層地質との相関が少しだけ良好であるこ とを示している。しかし、彼らの研究が地表を対象にしているのに対し、本研究では工学的基盤面を対 象にしているため、表層地質の影響が摇れや寸さの特性に現われ難くなったと考えられる。また、地質 の分布は形成された年代や形成方法により異なるため、地形の分布よりも複雑であり、限られた地震観 測点で作成した平均応答スペクトル比の空間分布図の分解能では、両者を比較するのは十分でないこと も考えられる。ただし、地形の分布との対応だけでは説明が難しいと判断した(3)小山町周辺が周期に関 係なく摇れやすい傾向は、地形に加え地質を考慮することで、「降下火山灰およびスコリアなど」の火山 山麓地に限定すれば、対応は良くなる。現状、スコリアなどの火山噴出物で構成される地盤が摇れやす い傾向を有することを明確に示寸既往の研究は見当たらない。しかし、例えばSato et al $(1997)^{36)}$ の研究 が示すとおりスコリア地盤が軟らかくてひずみが出やすいことは、火山噴出物の地盤が摇れやすい要因 として考えられる。

以上より、工学的基盤面における摇れや寸さの特性は、速度構造以外の影響として、一部複雑な地形 を除き、特に長周期において地形の要因が大きいと考えられる。ただし、地形だけで摇れやすさの特性 が決まるわけではなく、地形によっては地質なども影響を与えている。

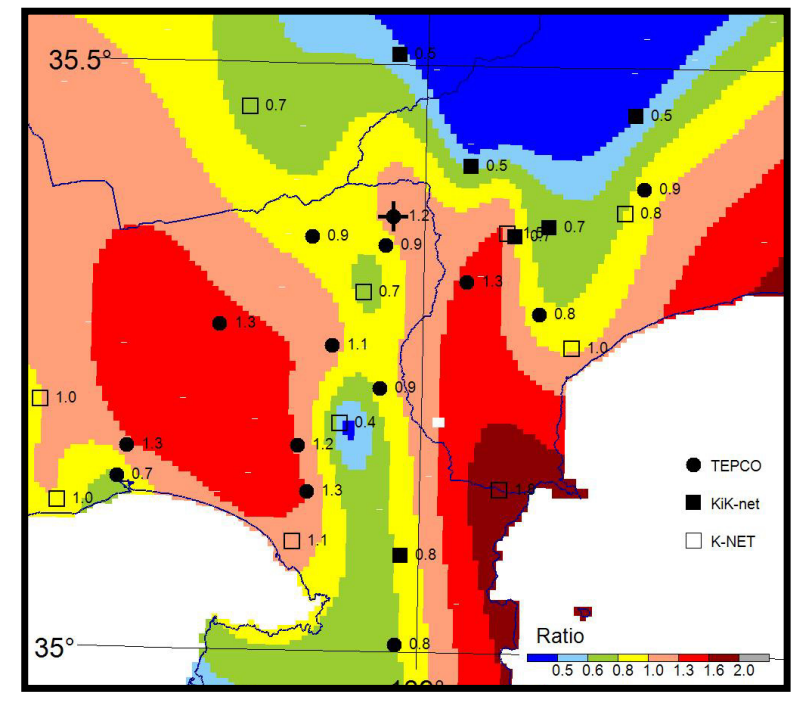

(a) 短周期側 $(0.02 \leqq T \leqq 0.2)$

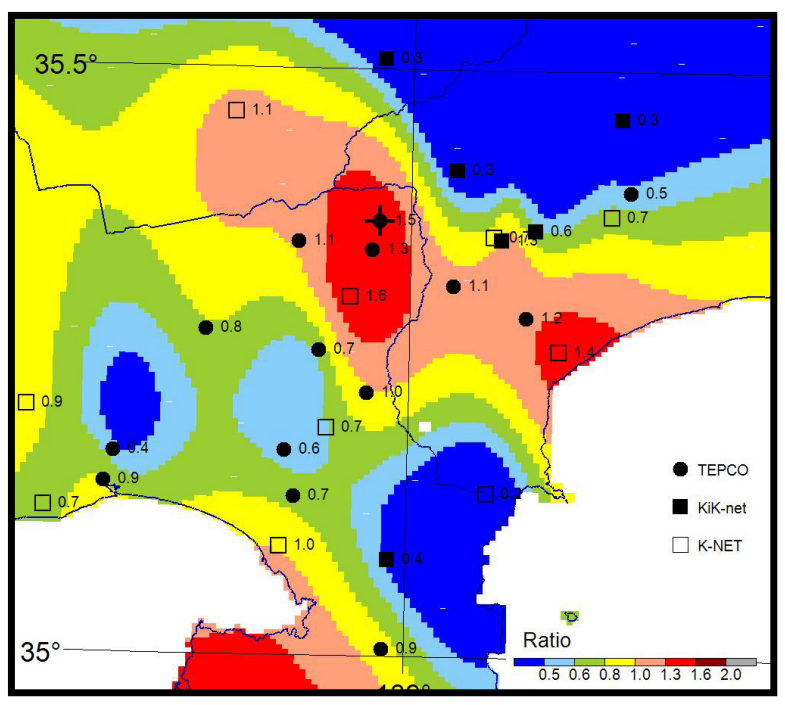

(b) 長周期側 $(0.7 \leqq T \leqq 2.0)$

図11 平均応答スペクトル比の空間分布 


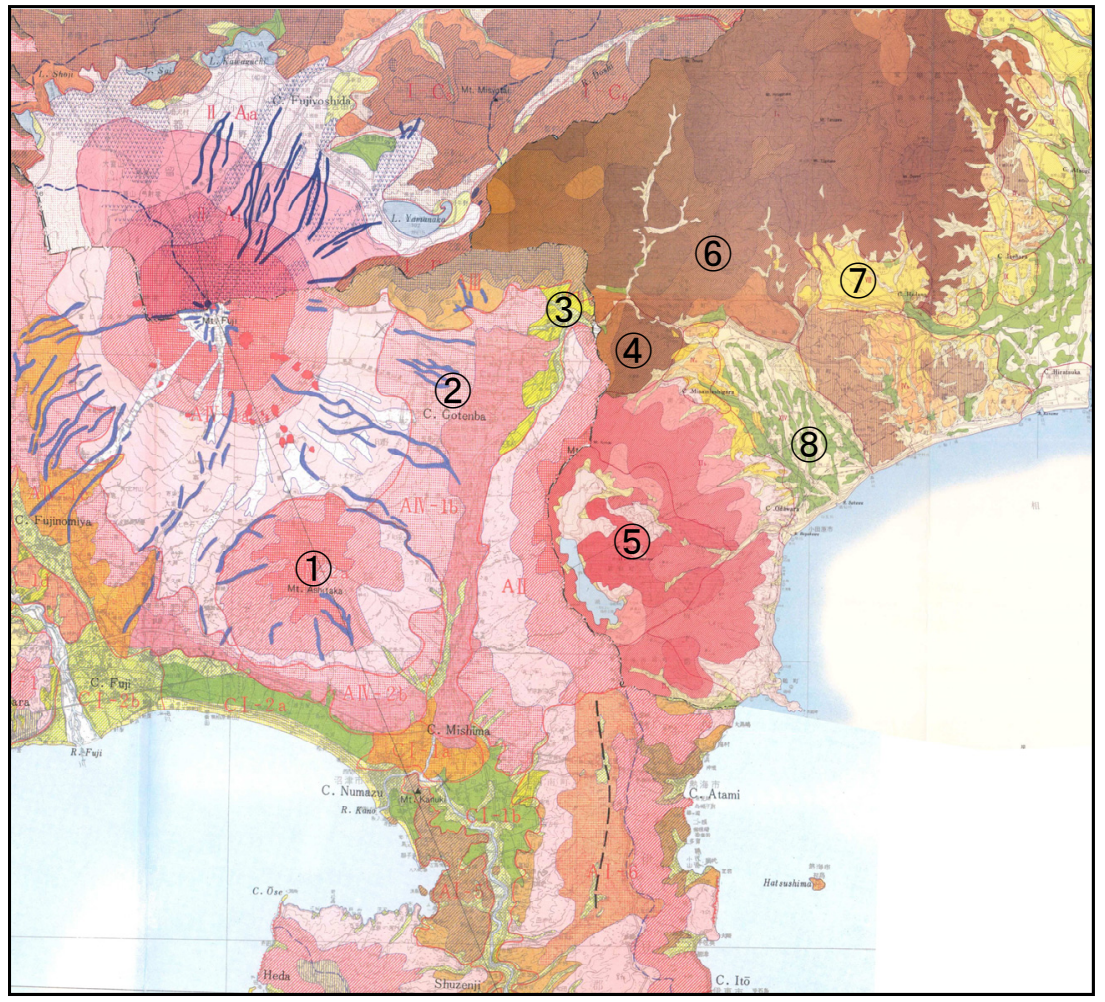

図12 地形分類図 (原図を編集) ${ }^{33}$
大起伏山地 (起伏量600m以上)

泥起伏山地 (起量 $400 \mathrm{~m}$ 以上 $600 \mathrm{~m}$ 未満)

小起伏山地 (起伏量 $200 \mathrm{~m}$ 以上 $400 \mathrm{~m}$ 未満)

山麓地 (起伏量 $100 \mathrm{~m}$ 以上 $200 \mathrm{~m}$ 未満)

山麓地 (起伏量100m未満)

小起伏丘陵地

大起伏火山地 (起伏量600m以上)

起伏火山地 (起伏量 $400 \mathrm{~m}$ 以上 $600 \mathrm{~m}$ 未満)

小起伏火山地 (起伏量200m以上400m未満)

火山山麓地 (神奈川県)

火山山麗地 (静岡県、起伏量 $100 \mathrm{~m}$ 以上 $200 \mathrm{~m}$ 未満)

火山山麓地 (静岡県、起伏量100m未満)

火山山簏地 (山梨県、起伏量 $100 \mathrm{~m}$ 以上200m未満)

火山山麓地 (山梨県、起伏量 $100 \mathrm{~m}$ 未満)

火山丘陵地

火山扇状地

溶岩台地·溶岩流

砂磁台地·段丘(中位面)

扇状地低地

三角州性低地

砂州·砂喽州

(1)愛鷹山、(2)御殿場市、(3)小山町、(4)足柄山地、(5)箱根山、(6)丹沢山地、(7)秦野盆地、8足柄平野

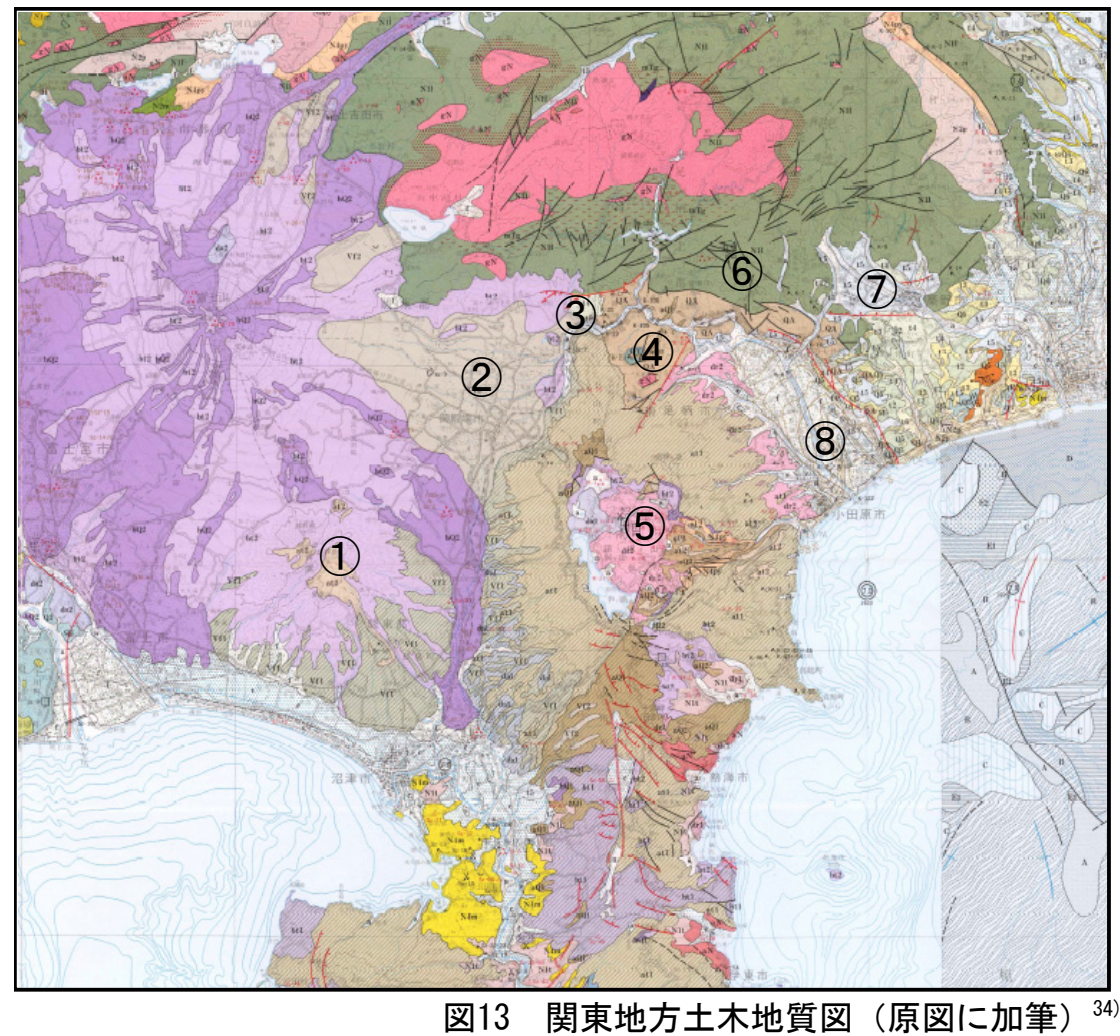

$\mathrm{QA} \begin{aligned} & \text { 砂岩、泥岩、礫岩 } \\ & \text { (火山砕屋岩、熔岩挟む) }\end{aligned}$

花崗岩類·閃緑岩類

(矢倉岳石英閃緑岩含む)

安山岩·流紋岩·玄武岩熔岩、

N11 凝灰岩、凝灰角砫岩

da2 岩屑なだれ堆積物

vf2 火山麓扇状地堆積物

(更新世後期 完新世)

Vf1 火山麓扇状地堆積物

(更新世前期 中期)

玄武岩質熔岩

(更新世後期〜完新世)

玄武岩質熔岩

(更新世前期〜中期)

安山岩熔岩

aQ1. 安山岩新世前期 中期)

デイサイト·流紋岩熔岩

(更新世後期 完新世)

玄武岩質降下火山灰および

bt2 スコリアなど(更新世後期〜完新世)

玄武岩質降下火山灰およひ

スコリアなど(更新世前期〜中期)

1 安山岩質降下火山灰および at1 スコリアなど(更新世前期〜 中期)

図13 関東地方土木地質図 (原図に加筆) ${ }^{34}$

(1)愛鷹山、(2)御殿場市、(3)小山町、(4)足柄山地、(5)箱根山、(6)丹沢山地、(7)秦野盆地、8)足柄平野 


\section{8 ゾーニング}

ゾーニングを実施するにあたりまず目安とするゾーニングとして、図11の平均応答スペクトル比の空 間分布図を基に、工学的基盤面における摇れや寸さの特性だけで短周期側と長周期側について個別にゾ ーニングを作成した。次に表5に示す周期帯別の摇れやすさの指標（閾值）を設定し、その組み合わせに よりグループを作成し、ゾーニングの領域を絞った。さらに、地形や地質の分布と比較することで、マ クロ的な観点から各グループ内で代表される地形・地質が支配的になるようにゾーニングの領域を絞っ た。地形の分布については国土地理院の 2 万千分の 1 地形図や図 $12 に$ 示寸地形分類図を、地質の分布につ いては図13に示す関東地方土木地質図を参考にした。ゾーニングした領域内に代表的な地形・地質では ない領域が局所的に含まれているが、そのような領域内にある地震観測点についてはそのグループを代 表する地点とすることは適切でないと判断し除去した。最後に、周期帯に関係なく平均応答スペクトル 比の形状の類似性をグループごとに確認し、大きく異なる地震観測点については除去することで、さら にゾーニングの領域を絞った。

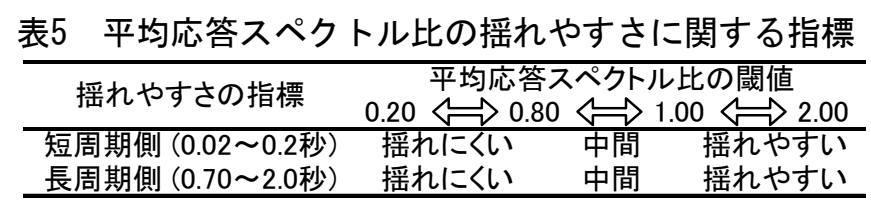

以上の方法に基づくゾーニング結果の概略図を図14に示す。今回の検討では他の地震観測点と平均応 答スペクトル比の形状が類似し、かつ地理的にも離れていない地震観測点だけで議論できるように、ま た平均応答スペクトル比の空間分布と地形・地質の分布とを比較する際に特徵を掴みやすくするために ゾーニングする領域を限定した。さらに、工学的基盤のS波速度が $300 \mathrm{~m} / \mathrm{sec}$ を回るK-NET小田原（KN G013）は除外した。表5より周期帯毎に3種類の摇れや寸さを設定したため、計9通りの組み合わせが考

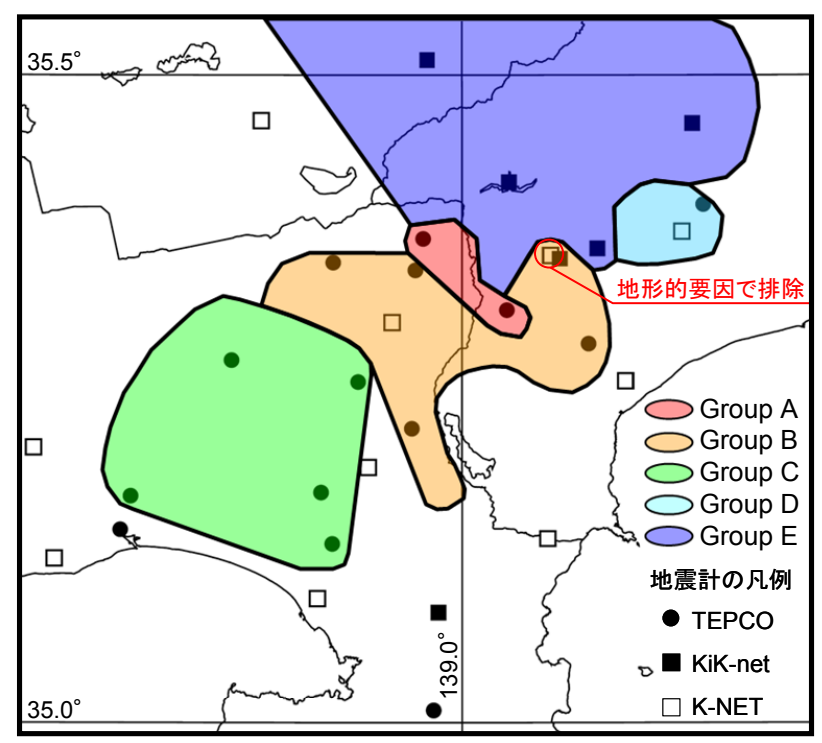

図14 ゾーニング結果の概略図

表6 各ゾーニンググループの特徵

\begin{tabular}{cccc}
\hline グループ & 短周期側(0.02 0.2秒) & 長周期側 $(0.70 \sim 2.0$ 秒 $)$ & 観測点数 \\
\hline A & 摇れやすい & 摇れやすい & 2 \\
B & 中間 $/$ 摇れにくい & 摇れやすい & 6 \\
C & 摇れやすい & 摇れにくい & 5 \\
D & 中間 & 摇れにくい & 2 \\
E & 摇れにくい & 摇れにくい & 4 \\
\hline
\end{tabular}


えられるが、今回の検討では長周期側での「中間」が無いため6通りの組み合わせとなった。また、表6 のようにBグループの短周期側の「中間」と「摇れにくい」は平均応答スペクトル比の形状などから1つ のグループにまとめたため、計5つのグループ分けとなった。また今回のゾーニングで地形や地質の分布 と比較した際に、各グループ内で代表される地形・地質ではないという理由から除去対象となった地点 は、グループB内に位置するK-NET山北（KNG014）のみである。K-NET山北周辺の2万5千分の1地形図 を図15に示す。図の $\square$ で示されているK-NET山北の地形は山地や丘陵に囲まれた盆地であることが確認 できる。一方、グループB内にある他の地震観測点の地形は火山地・火山山麓地または丘陵地であり、

K-NET山北とは地形が大きく異なる。実際に平均応答スペクトル比の形状に着目してみると、グループ Bに所属する他の地震観測点とK-NET山北の傾向には大きな違いがあった。K-NET山北と近傍の地震観 測点であるKiK-net山北南（KNGH22）の平均応答スペクトル比、およびグループBの平均応答スペクト ル比の平均值の比較を図16に示す。K-NET山北の平均応答スペクトル比は長周期側よりも短周期側の方 が大きいのに対し、KiK-net山北南の平均応答スペクトル比やグループBの平均応答スペクトル比の平均 值は逆に短周期側よりも長周期側の方が大きいことが図より確認できる。

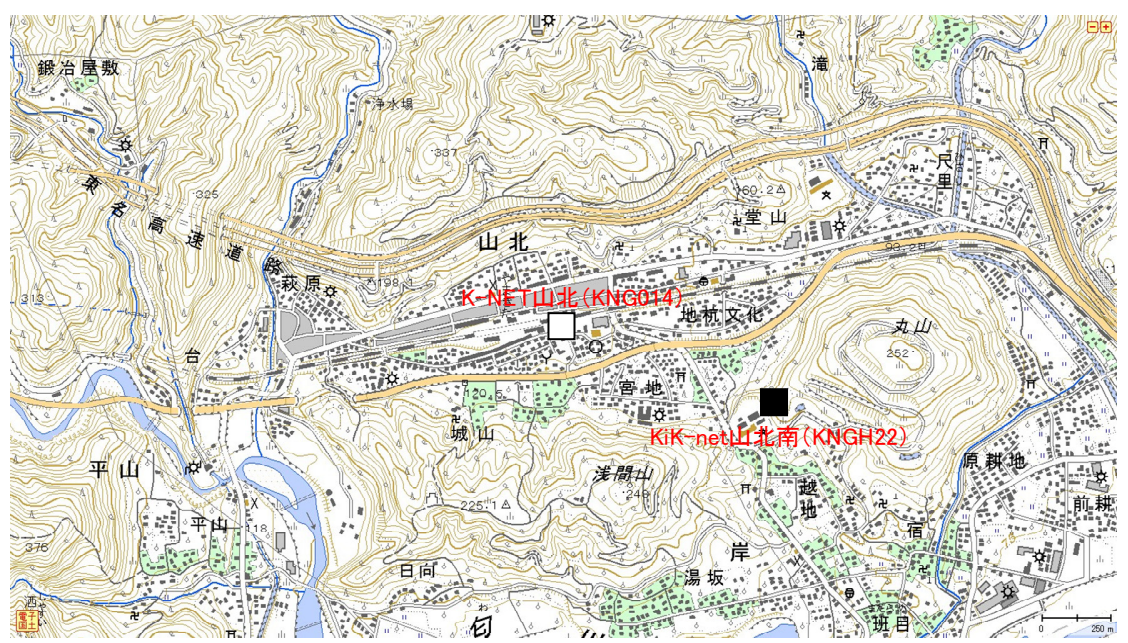

図15Ｋ-NET山北（KNG014）周辺の地形図（国土地理院の2万5千分の1地形図に加筆）

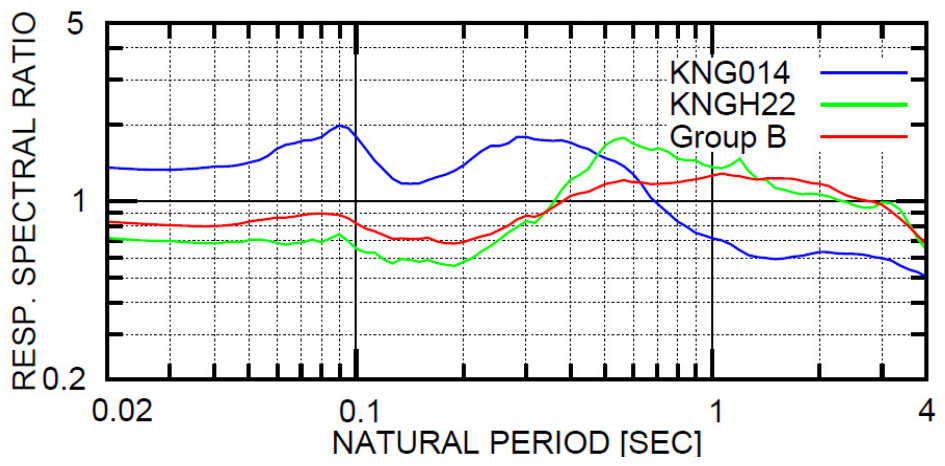

図16 K-NET山北（KNG014）とKiK-net山北南（KNGH22）の平均応答スペクトル比、 およびグループBの平均応答スペクトル比の平均値の比較

最終的にゾーニングの各グループを決定する際には、平均応答スペクトル比の形状を重要視した。平 均応答スペクトル比の形状の類似性については、推定式の適用範囲内の周期帯（Annaka and Nozawa (1988)の場合は0.02秒以上4秒以下）の平均応答スペクトル比の常用対数值から、全観測点の総当たりで 相関係数と残差二乗和（RSS）を求めることで定量的に評価した。相関係数は平均応答スペクトルの形 状の相似性を、残差二乗和は平均応答スペクトルの大きさをそれぞれ定量的に評価する指標として採用 した。相関係数と残差二乗和の関係について、各グループの代表 1 地点における結果を図17に示す。図17 
では右上ほど、すなわち正の相関関係が高く残差二乗和が小さいほど、互いの平均応答スペクトル比が 類似していることを示す。図17に示す各代表例とも他と比べて同じグループの地震観測点とは正の相関 性が高く、残差二乗和が小さい傾向が確認できる。グループC、D、Eに所属する大半の地震観測点の平 均応答スペクトル比は相関係数の值に大きな差は見られない（=相関性は類似している）が、これらに 残差二乗和を考慮することで、これら3つのグループにおける平均応答スペクトル比の形状の違いを、大 きさを指標として定量的に分離することが可能となる (=絶対值が異なる)。グループBは同様の考え方 でグループAとだいたい分離することができるが、グループAに関してはこの評価方法ではグループBと の分離が困難であるため、ゾーニングの際には表5に示す周期別の摇れや寸さの指標を重視した。どのグ ループにも所属しない地震観測点については、地理的・地形的条件と地質の不整合により予めグループ から除外している。
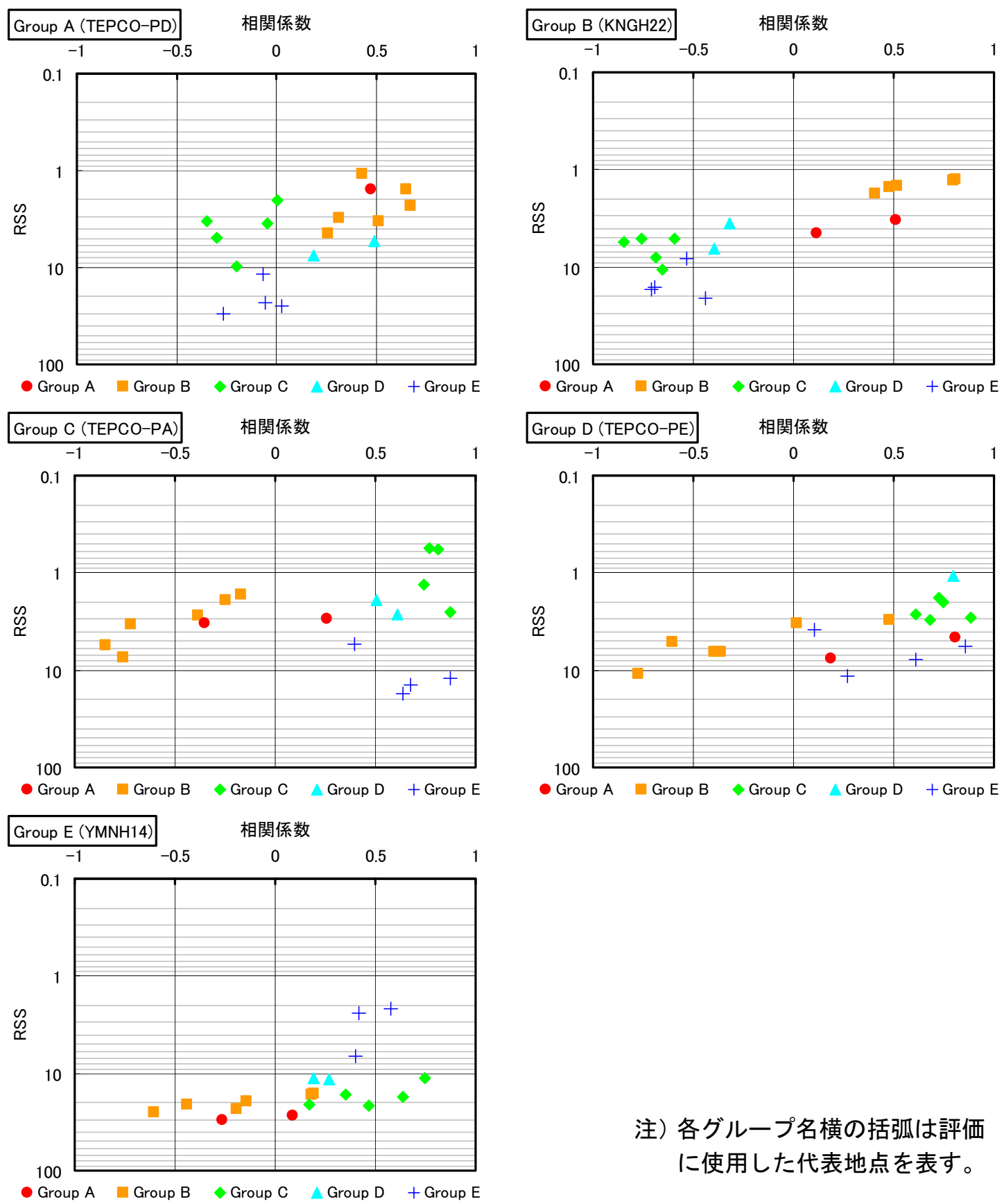

注）各グループ名横の括弧は評価 に使用した代表地点を表す。

図17 相関係数と残差二乗和の関係の一例 
以上のゾーニングにより得られた各グループの平均スペクトル比の分布とその幾何平均值を図18に示 し、また各グループの特徴を以下にまとめる。ただし、各グループの特徴に示してある地形・地質は対 象とする地理条件を満たす領域内の代表的なものであり、そのような地形・地質で構成されていない局 所的な地点については除外する。
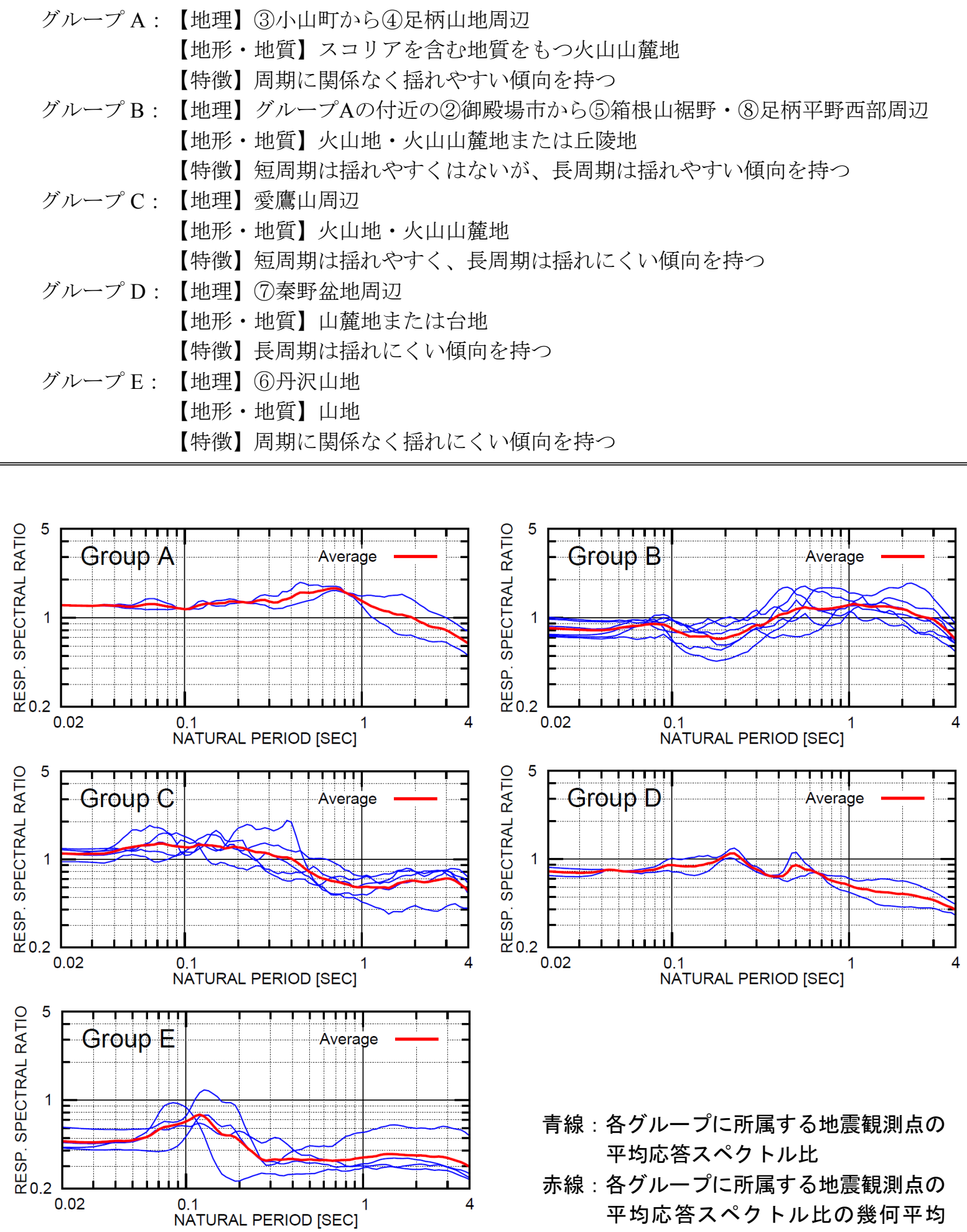

$\begin{aligned} & \text { 青線 : } \text { 各グループに所属する地震観測点の } \\ & \text { 平均応答スペクトル比 } \\ & \text { 赤線 : 各グループに所属する地震観測点の } \\ & \text { 平均応答スペクトル比の幾何平均 }\end{aligned}$

図18＼cjkstart各グループの平均応答スペクトル比の分布と平均值 


\section{3. ゾーニング結果に基づくエ学的基盤面の加速度応答スペクトルの推定方法}

\section{1 推定方法の提案}

ゾーニング結果から得られたグループ内の地震観測点の平均応答スペクトル比の平均值に平滑化処理 を施した值を、工学的基盤面における摇れや寸さ分布特性を考慮した地点補正倍率 $\alpha(T)$ と定義する。平 滑化処理には三角形分布の重みをもつ加重移動平均を用いた。各グループの地点補正倍率を図19に示す。

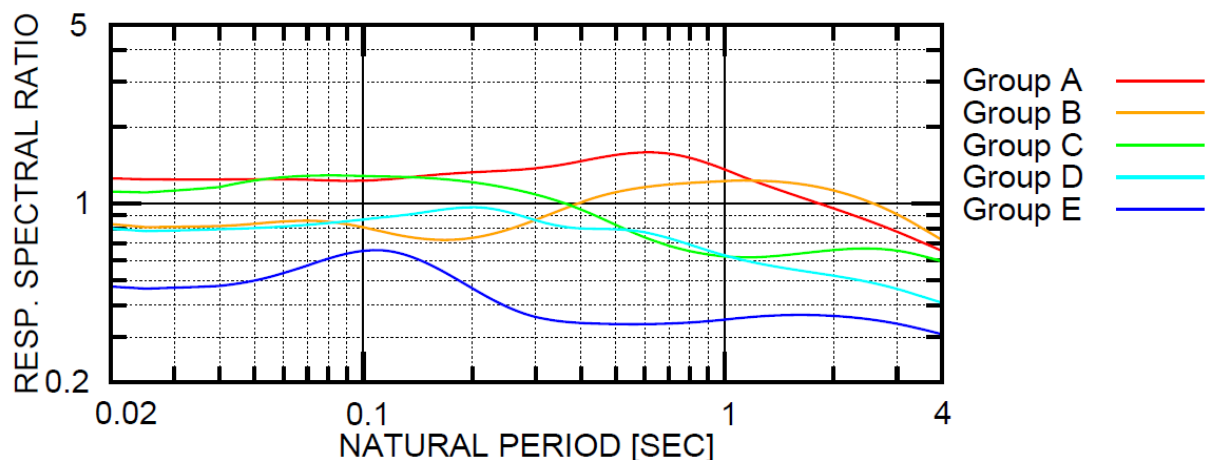

図19 各グループの地点補正倍率

地震観測地点が限られている広域を対象にした場合に、設計用の入力地震動を推定したい対象地点の 地理的・地形的条件や地質が5つのグループの中に該当するものがあれば工学的基盤面における摇れやす さの特性が同等のものであるとみなし、そのグループの地点補正倍率 $\alpha(T)$ を次式のように既存の加速度 応答スペクトル推定式 $S_{A}(T)$ （本研究ではAnnaka and Nozawa (1988)）に乗じることで、個別地点の摇れ やすさの傾向を反映した工学的基盤面における加速度応答スペクトル $S_{A}^{\prime}(T)$ を推定することが可能とな る。

$$
\log S_{A}^{\prime}(T)=\log S_{A}(T)+\log \alpha(T)
$$

\section{2 推定方法の検証}

前節で提案した推定手法と実際の観測記録とを比較することで、その有効性について検証する。地点 補正倍率の作成対象となった 30 地震観測点以外の観測記録と比較することが本来は望ましいが、新たな 観測点を設けて適切な観測記録を得ることは困難なため、本研究では各グループに所属する地震観測点 の観測記録との比較に代えた。ただし、作成した地点補正倍率は2.2節で述べたとおり2012年1月29日以 前の地震観測記録を使用しているので、検証にはそれ以降で収集された地震観測記録と比較する。2.3節 で示しているマグニチュード、最短距離および断層中心深さの3つの条件を満たす地震の中から、本研究 では2012年5月29日に千葉県北部の太平洋プレートとフィリピン海プレートの境界で発生した逆断層型

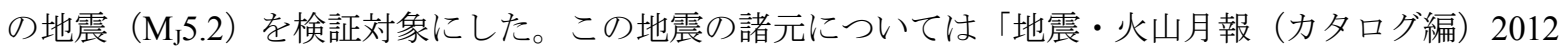
年5月」を使用した。結果の一例として、観測記録から算定した解放工学的基盤波、Annaka and Nozawa (1988)の推定式および本研究で提案した推定方法からそれぞれ算定した減衰 $5 \%$ 加速度応答スペクトル の比較を、各グループの代表1地点について図20に示す。また、各グループの代表1地点における観測記 録と推定式または提案した推定方法の残差二乗和の一例を表7にまとめる。本研究で提案した推定方法で は地点補正倍率に複数の地震観測記録の要素が含まれているため、対象の地震観測点のみで作成した地 点補正倍率に比べると精度は落ちてしまうが、それでも既往の推定式のみの結果に比べて本研究の推定 方法は観測記録と対応が良好になることが図20および表7より確認できる。特にグループEについては、 提案した推定方法を用いることで推定式と観測記録とのギャップが大幅に改善されている。 

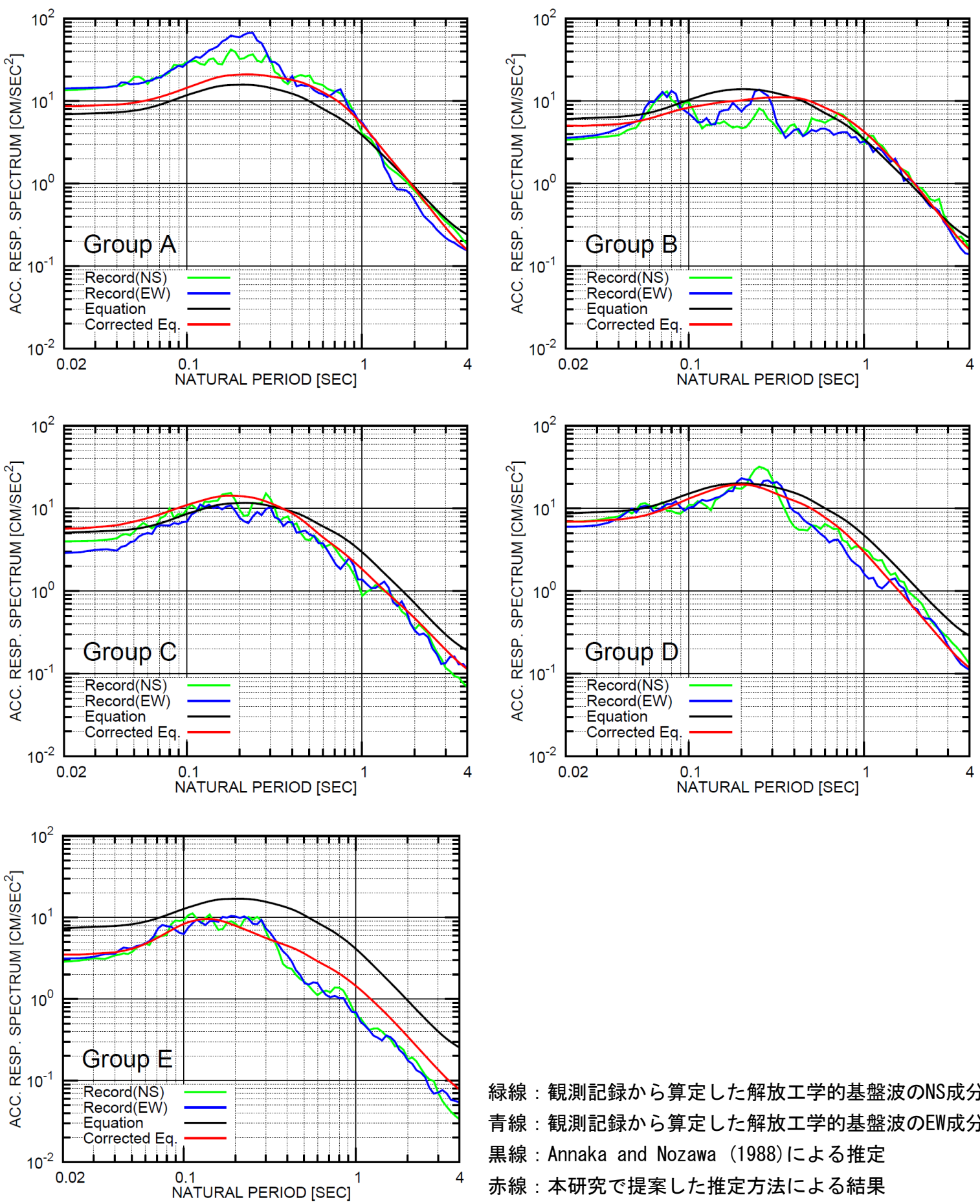

緑線：観測記録から算定した解放工学的基盤波のNS成分 青線：観測記録から算定した解放工学的基盤波のEW成分 黒線 : Annaka and Nozawa（1988)による推定 赤線 : 本研究で提案した推定方法による結果

図20 観測記録から算定した解放工学的基盤波の加速度応答スペクトル（減衰5\%）と 既往の推定式および提案した推定方法で算定した加速度応答スペクトルの比較の一例

表7 観測記録と既往の推定式または提案した推定方法との残差二乗和の一例

\begin{tabular}{|c|c|c|c|}
\hline \multirow{2}{*}{ グループ } & 解放工学的基盤波 & \multicolumn{2}{|c|}{ 残差二乗和 } \\
\hline & (観測記録)の成分 & & 提案方法 \\
\hline \multirow{2}{*}{ A } & $\overline{\mathrm{NS}}$ & 6.12 & 2.69 \\
\hline & EW & 9.30 & 4.96 \\
\hline \multirow{2}{*}{ C } & NS & 3.89 & 1.29 \\
\hline & $\mathrm{EW}$ & 3.69 & 2.28 \\
\hline \multirow{2}{*}{ E } & NS & 27.84 & 4.00 \\
\hline & EW & 26.95 & 3.95 \\
\hline
\end{tabular}

\begin{tabular}{|c|c|c|c|}
\hline & 解放工学的基盤波 & & 二乗和 \\
\hline クルーフ & (観測記録)の成分 & 既往 & 提案方法 \\
\hline $\mathrm{B}$ & $\overline{\mathrm{NS}}$ & $\overline{4.71}$ & $\overline{3.13}$ \\
\hline & EW & 3.50 & 2.96 \\
\hline D & NS & 3.16 & 1.51 \\
\hline
\end{tabular}




\section{4. まとめ}

本研究では、富士山南東部地域を対象に、地震観測記録から算定した平均応答スペクトル比を利用す ることで、工学的基盤面における摇れやすさについて空間的な分析を行った。次に、その分析結果と地 理的・地形的条件や地質の分布を比較することで、工学的基盤面における摇れやすさ分布特性に関する ゾーニングを検討した。工学的基盤面における摇れやすさ分布特性について検討結果を以下にまとめる。

・ 工学的基盤面における地震動の特性は一様ではなく、地域で異なっている。

・摇れや寸さ分布特性は基本的に地形の分布と対応が良好である。

・地質の分布と摇れやすさ分布特性との対応は地形ほど明瞭ではない。

・ただし、地形の分布との対応だけでは説明できない地域では、地形に加え地質を考慮することで、 対応は改善される。

以上の検討結果に加え、各地震観測地点の平均応答スペクトル比の形状を踏まえると、工学的基盤面 における摇れやすさ分布特性について、富士山南東部地域では地理的・地形的条件や地質の条件を代表

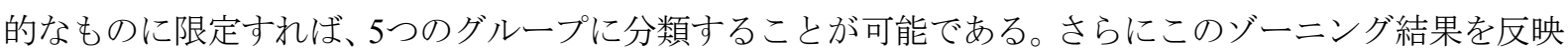
することで、空間的な摇れやすさ分布特性を考慮した工学的基盤面の加速度応答スペクトルの推定方法 を提案した。対象サイトが広域かつ複数の地形や地質の条件を有する場合に地震観測点でない地点につ いても、地理的・地形的条件や地質の情報を基に同一条件の地震観測点の経験的な摇れや寸さの傾向を 補間することで、入力地震動を推定することが可能となる。

本研究では平均応答スペクトル比の形状や地形・地質の分布との比較を検証する際の議論をしやすく するためにゾーニングの領域を敢えて限定しているが、今回の対象地域でゾーニングに含まれなかった 領域についても同様の手法を適応することでゾーニングを実施することは可能であると考えている。本 研究では富士山南東部地域を対象としたが、今後は本方法の他地域での適用性について検討する予定で ある。

\section{謝 辞}

本研究では、防災科学技術研究所によるK-NET・KiK-netの地震観測記録および土質データ、Hi-netの 気象庁一元化処理震源リスト、F-netの地震のメカニズム情報、Global CMT ProjectによるCMT解、国土地 理院による 2 万千分の 1 地形図、気象庁による地震・火山月報（カタログ編）を使用しました。関係機関 の皆様に謝意を表します。

\section{参考文献}

1) Abrahamson, N. and Silva, W. : Summary of the Abrahamson \& Silva NGA ground-motion relations, Earthquake Spectra, 24(1), 2008, pp.67-97.

2) Abrahamson, N. and Silva, W. : Errata for "Summary of the Abrahamson \& Silva NGA ground-motion relation" by Abrahamson, N. A. and W. J. Silva, Published on PEER NGA website.

3) Campbell, K. W. and Bozorgnia, Y. : Emirical ground motion model for shallow crustal earthquakes in active tectonic environments developed for the NGA project, Proceedings of Fourteenth World Conference on Earthquake Engineering, Paper no. 03-02-0004, 2008.

4) Campbell, K. W. and Bozorgnia, Y. : NGA ground motion model for the geometric mean horizontal component of PGA, PGV, PGD and 5\% damped linear elastic response spectra for periods ranging from 0.01 to $10 \mathrm{~s}$, Earthquake Spectra, 24(1), 2008, pp.139-171.

5) Chiou, B. S.-J. and Youngs, R. R. : An NGA model for the average horizontal component of peak ground motion and response spectra, Earthquake Spectra, 24(1), 2008, pp.173-215.

6) 大西淳一、山崎文雄、若松加寿江 : 気象庁地震記録の距離減衰式に基づく地点増幅特性と地形分類と の関係、土木学会論文集、No.626、I-48、1999 年、pp.79-91.

7) 野津厚、長尾毅、山田雅之 : スペクトルインバージョンに基づく全国の強震観測地点におけるサイト 増幅特性とこれを利用した強震動評価事例、日本地震工学会論文集 第 7 巻、第 2 号（特集号）、2007 年、 pp.215-234. 
8) 片岡正次郎、松本俊輔、日下部毅明、遠山信彦 : やや長周期地震動の距離減衰式と全国の地点補正倍 率、土木学会論文集 A、Vol.64、No.4、2008 年、pp.721-738.

9) 先名重樹、翠川三郎 : 地形・地盤分類に基づく地震動のスペクトル増幅率の推定、日本地震工学会論 文集 第 9 巻、第 4 号、 2009 年、pp.11-25.

10) Annaka, T., T. Tsuzuki, K. Etsunaga, and M. Shimada : Bayesian estimation of strain dependence of dynamic soil properties from the strong motion accelerograms recorded by a vertical array, Proceedings of Eleventh World Conference on Earthquake Engineering, 1996, Paper No. 602.

11) Annaka, T. and Nozawa, Y. : A probabilistic model for seismic hazard estimation in the Kanto district, Proceedings of Ninth World Conference on Earthquake Engineering, Vol.II, 1988, pp.129-132.

12) Kanno, T., A. Narita, N. Morikawa, H. Fujiwara, and Y. Fukushima : A New Attenuation Relation for Strong Ground Motion in Japan Based on Recorded Data, Bull. Seism. Soc. Am. Vol.96, 2006, pp.879-897.

13) Pacific Earthquake Engineering Reserch Center : Next Generation Attenuation Database, http://peer.ber keley.edu/nga/

14) Seno, T., K. Shimazaki, P. Somerville, K. Sudo and T. Eguchi : Rupture process of the Miyagi-Oki, Japan, earthquake of June 12, 1978, Phys. Earth Planet. Inter., 21, 1980, pp.39-61.

15) 菊池正幸、須藤研：1982 年 7 月 23 日茨城県沖地震の震源過程、月刊地球、7、1985 年、pp.72-78.

16) 岡田義光、笠原敬司：1987 年 12 月千葉県東方沖地震、地震学会 1988 年春期大会講演予稿集、1988

年、 pp.63.

17) 望月英志、大林政行：1990 年 2 月 20 日伊豆大島近海地震の断層パラメタ、地震学会 1990 年秋季大 会講演予稿集、1990 年、pp.57.

18) 浅野公之、岩田知孝、入倉孝次郎：2003 年 5 月 26 日に宮城県沖で発生したスラブ内地震の震源モ デルと強震動シミュレーション、地震第 2 輯、57、2004 年、pp.171-185.

19）国土地理院: 平成 15 年（2003 年）十勝沖地震（Mj8.0）に伴う地殼変動と断層モデル、十勝沖の地 震の評価、地震調査研究推進本部 HP、http://www.jishin.go.jp/main/chousa/03oct_tokachi/p11.htm、2003 年.

20) 山中佳子:EIC 地震学ノート、No.154、http://www.eri.u-tokyo.ac.jp/sanchu/Seismo_Note/2004/EIC154.html、 2004 年.

21) 国土地理院 : 紀伊半島南東沖の地震 断層モデル(1)、紀伊半島南東沖の地震活動の評価、地震調査 研究推進本部 HP、http://www.jishin.go.jp/main/chousa/04oct_kiihantou/p07.htm、2004 年.

22) Hikima, K. and Koketsu, K. : Rupture process of the 2004 Chuetsu (mid-Niigata prefecture) earthquake, Japan, A series of events in a complex fault system, GRL, 32, L18303, 2005.

23) 東京大学地震研究所 : 近地強震計データによる 2004 年 10 月新潟県中越地震の震源過程（速報）、 http://www.eri.u-tokyo.ac.jp/sanchu/Seismo_Note/2004/041023Knet.pdf、2004 年.

24) 国土地理院 : 2005 年 8 月 16 日 宮城県沖の地震に伴う断層モデル（最終解）、宮城県沖の地震活動 の評価、地震調查研究推進本部 HP、http://www.jishin.go.jp/main/chousa/05sep_miyagi/p09.htm、2005 年.

25) 国土地理院：平成 19 年（2007 年）能登半島地震 断層モデルと水平変動および上下変動、平成 19 年（2007 年）能登半島地震の評価、地震調查研究推進本部 HP、http://www.jishin.go.jp/main/chousa/07apr noto/p09.htm、2007 年.

26) 国土地理院 : 平成 19 年新潟県中越沖地震 推定された主要なすべり面の概念図、平成 19 年 (2007

年）新潟県中越沖地震の評価（主に断層面に関寸る評価）、地震調查研究推進本部 HP、http://www.jishin. go.jp/main/chousa/08jan_chuetsu_oki/p06.htm、2008 年.

27) 山中佳子:NGY 地震学ノート、No.7、http://www.seis.nagoya-u.ac.jp/sanchu/Seismo_Note/2008/NGY7.html、 2008 年.

28) 国土地理院 : 震源モデルと地殼変動、2009 年 8 月 11 日駿河湾の地震活動の評価、地震調査研究推 進本部 HP、http://www.jishin.go.jp/main/chousa/09sep_suruga-wan/p07.htm、2009 年.

29) 気象庁・気象研究所：「平成 23 年（2011 年）東北地方太平洋沖地震」の断層すべり分布の推定一近 地強震波形を用いた解析一、http://www.seisvol.kishou.go.jp/eq/sourceprocess/event/20110311near.pdf、2011 年.

30) 国土地理院 : 2011 年 3 月 15 日静岡県東部の地震（M6.4）の震源断層モデル（暫定）、地震調査研究 
推進本部 HP、http://www.jishin.go.jp/main/chousa/11apr/p23.htm、2011 年.

31) 国土地理院：2011 年 4 月 7 日宮城県沖の地震（M7.1）の震源断層モデル（暫定）、地震調査研究推 進本部 HP、http://www.jishin.go.jp/main/chousa/11may/p09.htm、2011 年.

32) 国土地理院：2011 年 4 月 12 日千葉県東方沖の地震（M6.4）の震源断層モデル（暫定）、地震調査研 究推進本部 HP、http://www.jishin.go.jp/main/chousa/11may/p26.htm、2011 年.

33) 塩野政治、升本眞二、弘原海清 : BASIC によるコンターマップ II 応用編、共立出版、1988 年 11 月.

34) 土地分類図（静岡県、山梨県、神奈川県）、国土庁土地局国土調査課、1971～1975 年.

35) 関東地方土木地質図、関東地方土木地質図編纂委員会、1996 年.

36) Sato, T., M. Horike, Y. Takeuchi, T. Uetake and H. Suzuki : Nonlinear behaviour of scoria soil sediments evaluated from borehole records in eastern Shizuoka prefecture, Japan, Earthquake Engineering and Structural Dynamics, 26, 1997, pp.781-795.

(受理：2013年 8 月 15 日)

（掲載決定：2014年 2月 10日）

\title{
Estimate of Acceleration Response Spectra on Engineering Bedrock Considering Spatial Distribution Characteristics of Seismic Motion Intensities
}

\author{
SHINGAKI Yoshikazu ${ }^{1)}$, KURITA Tetsushi ${ }^{2)}$, ANNAKA Tadashi ${ }^{3)}$ and \\ MORI Yoshiki ${ }^{4)}$
}

1) Member, Tokyo Electric Power Services Co., Ltd., M. Eng.

2) Member, Tokyo Electric Power Services Co., Ltd., Dr. Eng.

3) Member, Tokyo Electric Power Services Co., Ltd., M. Sc.

4) Tokyo Electric Power Company

\begin{abstract}
We studied the spatial distribution characteristics of seismic motion intensities on the engineering bedrock around the southeastern Mt. Fuji region by using the seismic records. We used the ratios of response spectra between the observed record and calculated values by the existing attenuation relations as the index of seismic motion intensities. We compared the spatial distribution characteristics with topographical maps and geological maps. As a result of the zoning, the region was classified into five groups. Based on the zoning, we calculated the factors to correct the attenuation relation. The factors reflect the spatial distribution characteristics of each zoning group. We propose a new method to estimate acceleration response spectra on the engineering bedrock spread over a wide area.
\end{abstract}

Keywords: Spatial distribution characteristics of seismic motion intensities, Zoning, Acceleration response spectra, Topography, Geology 